\title{
Pendampingan Desa Wisata Garongan: Program Kerjasama Sekolah Tinggi Pariwisata AMPTA Yogyakarta dengan Kementrian Pariwisata dan Ekonomi Kreatif
}

\author{
Hary Hermawan ${ }^{1}$, Iputu Hardani Hesti Duari ${ }^{2}$, Hermawan Prasetyanto ${ }^{3}$, Angela \\ Ariani $^{4}$, Santosa ${ }^{5}$, Hamdan Anwari ${ }^{6}$, Prihatno ${ }^{7}$, Nikasius Jonet Sinangjoyo ${ }^{8}$, Arif Dwi \\ Saputra', Florin Limantoro Lim $^{10}$, Fera Eka Cahyani ${ }^{11}$, Heri Setyo Sudarso ${ }^{12}$, Kiki \\ Novia Prasasti ${ }^{13}$, Khelvin ${ }^{13}$ \\ ${ }^{1-13}$ Sekolah Tinggi Pariwisata AMPTA, Yogyakarta, Indonesia, email:haryhermawan8@gmail.com
}

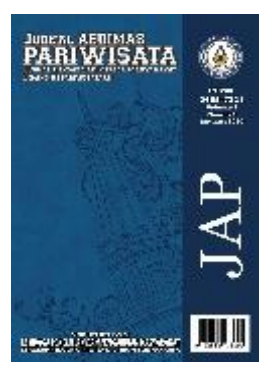

\begin{tabular}{ll}
\hline \multicolumn{2}{l}{ Informasi artikel } \\
\hline $\begin{array}{l}\text { Sejarah } \\
\text { artikel }\end{array}$ & \\
$\begin{array}{l}\text { Diterima } \\
\text { Revisi }\end{array}$ & $:$ 1 Desember 2020 \\
Dipublikasikan & $:$ 1 Danuari 2021
\end{tabular}

\section{Kata kunci:}

Pendampingan

Desa Wisata

Kemenparekraf

Garongan

\begin{abstract}
ABSTRAK
Desa Wisata Garongan merupakan salah satu desa wisata berkembang di Daerah Istimewa Yogyakarta. Desa wisata ini memiliki potensi wisata yang sangat besar, meliputi: aset wisata alam, wisata budaya, kuliner, termasuk latar belakang sejarahnya yang menarik. Disamping banyaknya potensi daya tarik wisata yang ada, masih ditemukan kelemahan dalam pengelolaan Desa Wisata Garongan. Kegiatan pendampingan ini merupakan hasil kerjasama Sekolah Tinggi Pariwisata AMPTA Yogyakarta dengan Kementrian Pariwisata dan Ekonomi Kreatif/Badan Pariwisata dan Ekonomi Kreatif. Dari hasil pendampingan diukur dengan indikator keberhasilan maka kegiatan ini dianggap cukup berhasil dalam meningkatkan kapastitas sumber daya manusia dan tata kelola Desa Wisata Garongan.

\section{ABSTRACT}

\begin{tabular}{l} 
ABSTRACT \\
\hline Mentoring of Garongan Tourism Village: Sekolah Tinggi \\
Pariwisata AMPTA Yogyakarta Collaboration Program with \\
the Kementrian Pariwisata dan Ekonomi Kreatifl Badan \\
Pariwisata dan Ekonomi Kreatif. Garongan Tourism Village is \\
one of the developing tourism villages in the Yogyakarta Special \\
Region. This tourism village has enormous tourism potential, \\
including natural tourism assets, cultural tourism, culinary tours, \\
including an interesting historical background. In addition to the \\
many potential tourist attractions that exist, weaknesses are still \\
found in managing the Garongan Tourism Village. This mentoring \\
activity results from a collaboration between the Sekolah Tinggi \\
Pariwisata AMPTA Yogyakarta and Kementrian Pariwisata \\
dan Ekonomi Kreatiff Badan Pariwisata dan Ekonomi \\
Kreatif. From the results of assistance measured by indicators of \\
success, this activity is considered quite successful in increasing \\
human resources and governance of the Garongan Tourism \\
Village.
\end{tabular}
\end{abstract}

Keywords: mentoring Tourism Village Kemenparekraf Garongan

\section{Pendahuluan}

Otonomi daerah mendorong perubahan pada pola berfikir masyarakat serta mendorong seluruh aparat pemerintahan daerah bersama masyarakat untuk dapat menggali potensi dan permasalahan wilayahnya secara komprehensif, serta memanfaatkan potensi tersebut secara optimal berdasarkan ukuran dan skala prioritas desa (Permendagri 56 atau 2015). Selain itu, otonomi daerah juga memberikan dorongan perekonomian daerah yang lebih terbuka dalam menggali potensi sumber daya alam, ekonomi, dan sosial secara lebih komprehensif dan bersinambungan antar bidang yang ada.

Desa wisata menjadi salah satu kegiatan usaha yang mampu memberikan kontribusi bagi perkembangan dan kemajuan masyarakat desa. Namun dalam perkembangannya, masih banyak hal 
yang perlu dikaji ulang tentang konsep desa wisata yang berkelanjutan melalui beberpa program yang telah dicanangkan oleh pemerintah. Tujuan program-program pemerintah tersebut adalah terwujudnya perkembangan desa wisata, dari desa tertinggal menjadi desa berkembang sebanyak 10.000 ribu desa, terwujudnya desa berkembang menjadi desa mandiri sebanyak 5.000 desa, terwujudnya revitalisasi kawasan perdesaan sebanyak 60 kawasan perdesaan, terwujudnya revitalisasi kawasan transmigrasi sebanyak 63 kawasan transmigrasi dan terentaskannya daerah tertinggal sebanyak 25 kabupaten tertinggal (5 Target Kemendes dalam RPJMN 2020-2024).

Namun dari beberapa program pemerintah tersebut dipandang masih perlu untuk difokuskan tindak lanjutnya agar mampu memberikan kontribusi nyata bagi perkembangan desa, termasuk program yang tepat sasaran, dan tepat guna. Sehingga, dengan berbagai program yang ada, masyarakat mampu mandiri secara ekomoni untuk mengolah sumber daya alam yang dimiliki.

Desa adalah kesatuan masyarakat yang merupakan subyek utama yang harus dibimbing untuk pengembangan potensi dan aset desa guna mewujudkan kesejahteraan bersama, memajukan perekonomian desa, serta mengatasi kesenjangan pembangunan (UU No 6 atau 2014). Sehingga, kecenderungan untuk menggantungkan diri pada bantuan pemerintah perlahan-lahan dapat dihilangkan. Termasuk keahlian sumber daya manusia dalam mengelola potensi desanya menjadi meningkat secara optimal.

Desa Wisata Garongan merupakan salah satu desa wisata berkembang di Daerah Istimewa Yogyakarta (www.desawisatagarongan.com). Desa wisata ini memiliki potensi wisata yang sangat besar, meliputi: aset wisata alam, wisata budaya, kuliner, termasuk latar belakang sejarahnya yang menarik (www.jogjasuper.co.id).

Potensi daya tarik wisata alam yang ada di Desa Wisata Garongan sangat lengkap sehingga jika dikelola dengan baik akan mampu menawarkan pengalaman wisatawan yang memuaskan, baik pengalaman wisata secara pasif, maupun pengalaman secara aktif (Hidayah, 2019). Potensi daya tarik wisata di Desa Wisata Garongan yang menawarkan pengalaman wisata pasif meliputi: (1) Pemandangan alam yang indah karena lokasi desa berada di lereng Gunung Merapi; (2) Suasana alam khas pedesaan di Yogyakarta yang masih asri; (3) Udara yang sejuk jauh dari polusi; (4) Lingkungan yang baik, dengan sumber mata air yang banyak; (5) Hamparan perkebunan buah salak yang subur serta hasil budidaya ikan yang sangat melimpah; (6) Memiliki tradisi budaya Budaya Gejlok Lesung; (7) Latar belakang sejarah yang unik. Sedangkan daya tarik wisata aktif yang dapat dinikmati wisatawan saat ini meputi: (1) Aktifitas berkemah dengan luas camping ground sekitar 6000 meter persegi yang dapat menampung kurang lebih 500 peserta camping; (2) Aktifitas agrowisata salak, memetik salak, memanen, dan sebagainya (Data observasi, 2020).

Disamping banyaknya potensi daya tarik wisata yang ada, masih ditemukan beberapa kelemahan dalam pengelolaan Desa Wisata Garongan. Permasalahan pertama adalah masyarakat di Desa Wisata Garongan mayoritas belum memiliki pemahaman yang baik terkait sapta pesona pariwisata, sehingga berdampak pada masih lemahnya kualitas produk dan pelayanan pariwisata. Terkait dengan adanya pandemi Covid-19, maka dipandang perlu juga untuk meningkatkan pemahaman pengelola terkait penerapan Clean Hygiene Safety Enviroment (CHSE). CHSE merupakan pengetahuan dan praktik baru yang belum banyak dipahami pengelola desa wisata. Namun, CHSE saat ini wajib diterapkan oleh seluruh pengelola jasa wisata guna menjamin keamanan dan keselamatan wisatawan dari wabah dan penyakit, khususnya Covid-19.

Permasalahan kedua, pengelola belum memiliki kompetensi standar dalam memberikan pelayanan jasa wisata, terutama pelayanan pramuwisata. Dalam hal ini, pengelola masih merasa kurang dalam hal mengelola dan mengemas potensi desanya menjadi daya tarik wisata dengan narasi yang baik sehingga menarik untuk dapat diceritakan kepada wisatawan sehingga wisatawan memperoleh pengalaman wisata yang berkesan. Selain itu, pengelola juga merasa belum percaya diri dalam memberikan pelayanan pemanduan, meliputi bagaimana menyapa tamu yang baik, cara menghdupkan suasana tour, dan lain sebagainya

Permasalahan ketiga yaitu kurangnya pemahaman dan kemampuan pengelola dalam hal tata kelola pelayanan, khususnya terkait operasional usaha homestay. Menurut Bapak Agus selaku pengurus Pokdarwis Desa Wisata Garongan mengatakan bahwa masih banyak pengelola homestay 
yang belum sadar wisata. Selain itu, pengelola homestay masih belum bisa memberikan pelayanan yang standar kepada wisatawan, misalnya dalam hal upaya menjaga kebersihan homestay, menciptakan kenyamanan tamu yang menginap, dan perawatan fasilitas dan lain sebagainya. Termasuk masih lemahnya sistem administrasi. Permasalahan pada ruang lingkup tata kelola desa wisata yang lebih luas, adalah pengelola belum memiliki kemampuan yang baik dalam hal manajemen keuangan, misalnya terkait dengan perencanaan program kerja.

Permasalahan keempat, pengelola belum memiliki kemampuan dalam hal pengolahan bahan makanan menjadi produk-produk olahan yang unik dan bernilai jual, termasuk belum memiliki cara penyajian yang mampu menjadi daya tarik kuliner khas Desa Wisata Garongan. Sebagai contoh, hasil perikanan air tawar Desa Garongan sangat melimpah, namun sampai saat ini mayoritas masih dijual mentah di pasar ikan. Jika dimasak hanya sebatas digoreng atau dibakar seperti pada umumnya. Padahal, olahan ikan dapat dibuat dan disajikan dengan berbagai macam gaya yang diharapkan mampu menjadi daya tarik wisata kuliner desa atau yang lebih mendetail seperti wisata gastronomi

Permasalahan terakhir, pengelola belum mampu memenuhi permintaan paket wisata dengan baik. Padahal, permintaan tour dari desa wisata ke destinasi lain juga sangat diminati tamu, terutama bagi wisatawan yang berkunjung ulang (repeater). Selain menambah pengalaman wisata, penjualan paket wisata ke destinasi lain seharusnya mampu menambah durasi wisata, sehingga pendapatan desa wisata dari pembelanjaan wisatawan di desa akan semakin optimal (Data observasi dan wawancara, 2020).

Desa Wisata Garongan membutuhkan upaya peningkatan pelayanan serta peningkatan kualitas produknya untuk dapat menjadi desa wisata maju. Oleh karena itu, Sekolah Tinggi Pariwisata AMPTA berupaya menyelesaikan berbagai permasalahan Desa Wisata Garongan melalui kegiatan Pengabdian Kepada Masyarakat (PKM) "Program Pendampingan dan Percepatan Desa Wisata Garongan Menuju Desa Wisata Maju."

Sasaran program ini adalah masyarakat lokal selaku pengelola desa wisata yang tergabung dalam Kelompok Sadar Wisata (Pokdarwis) beserta pelaku usaha pariwisata di Desa Wisata Garongan. Sedangkan tujuan program pendampingan ini meliputi : (1) Merubah paradigma masyarakat terhadap pariwisata melalui sosialisasi dan pelatihan gerakan sadar wisata untuk mewujudkan sapta pesona pariwisata; (2) Meningkatkan kompetensi dan profesionalisme pelaku wisata di Desa Wisata Garongan dalam memberikan pelayanan yang terbaik, serta bebas dari risiko bahaya penyakit akibat Covid 19; (3) Meningkatkan kompetensi pengelola dalam standar operasional usaha jasa pariwisata di Desa Wisata Garongan, meliputi: usaha homestay, usaha restoran, dan biro perjalanan wisata (5) Menciptakan produk Desa Wisata Garongan berkualitas secara keseluruhan, yang menuhi kriteria: keunikan, estetika, asli, aman, nyaman, berbasis pada nilai-nilai kearifan; (6) Meningkatkan kemampuan pengelola dalam manajemen desa wisata, terutama dalam hal pemasaran dan pengelolaan keuangan. Sehingga, output secara umum dari program pendampingan ini adalah percepatan Desa Wisata Garongan menjadi desa wisata maju yang berkelanjutan.

Kegiatan pendampingan ini dimaksudkan sebagai untuk membantu percepatan pembangunan Desa Wisata Garongan, dari desa wisata berkembang menjadi desa wisata maju yang berkelanjutan. Sekaligus sebagai pemenuhan dharma ke tiga dari perguruan tinggi yaitu pengabdian kepada masyarakat (community service)

Tujuan dari kegiatan pelaksanaan kegiatan Pengabdian kepada Masyarakat (PkM) "Program Pendampingan dan percepatan Desa Wisata Berkembang Menuju Desa Wisata Maju," adalah untuk memperbaiki berbagai kelemahan yang ada dalam pengelolaan Desa Wisata Garongan, meliputi : (1) Memberikan pengetahuan dan kemampuan kepada mitra (masyarakat ) dalam upaya mewujudkan sapta pesona pariwisata; (2) Memberikan pengetahuan dan keterampilan kepada mitra (masyarakat) mengenai kompetensi standar pelayanan pemandu wisata yang professional dengan penerapan pelayanan prima dan hospitality; (3) Memberikan pengetahuan dan kemampuan kepada mitra (masyarakat ) mengenai standar operasional usaha homestay serta disertai pemahaman dan penerapan Clean Hygiene Safety Enviroment (CHSE); (4) Memberikan pengetahuan dan kemampuan kepada mitra (masyarakat ) dalam hal perencanaan produk desa wisata berbasis nilai keunggulan lokal dengan metode Exploring, Packaging, Presentation (EPP), meliputi: inventarisasi potensi daya tarik wisata, 
pengemasan paket wisata dan promosi produk melalui berbagai media; (5) Memberikan pengetahuan dan kemampuan kepada mitra (masyarakat ) dalam hal manajemen keuangan desa wisata; (6) Memberikan pengetahuan dan kemampuan kepada mitra (masyarakat) dalam hal pengolahan bahan makanan menjadi produk-produk olahan yang unik dan bernilai jual. Termasuk cara penyajian yang mampu menjadi daya tarik kuliner khas Desa Wisata Garongan.

Sasaran utama dari program pendampingan ini adalah masyarakat Desa Wisata Garongan, adapun kompenen masyarakat yang dimaksud meliputi: (1) Anggota Kelompok Sadar Wisata (Pokdarwis) Desa Wisata Garongan; (2) Masyarakat pengelola usaha pendukung pariwisata, meliputi: kelompok homestay, kelompok kuliner PKK, kelompok pertanian, dan kelompok peternakan

Terget kegiatan pendampingan Desa Wisata Garongan meliputi: (1) Meningkatkan kompetensi dan profesionalisme pelaku wisata di Desa Wisata Garongan dalam memberikan pelayanan jasa pariwisata; (2) Meningkatkan kompetensi pengelola dalam menyediakan pelayanan prima dalam usaha jasa pariwisata Desa Wisata Garongan, meliputi: peningkatan standar usaha homestay, Penerapan CHSE, peningkatan kompetensi dalam manajemen keuangan, termasuk peningkatan kompetensi dalam pengembangan dan pemasaran produk desa wisata; (3) Menciptakan produk-produk olahan makanan dari Desa Wisata Garongan berkualitas secara keseluruhan, yang menuhi kriteria: unik, asli, berbasis pada nilai-nilai kearifan lokal sesuai prinsip-prinsip pariwisata berbasis masyarakat.

\section{Metode}

Kegiatan pendampingan desa wisata dilakukan di Desa Wisata Garongan. Secara administratif, Desa Wisata Garongan Terletak di Desa Wonokerto, Kecamatan Turi, Kabupaten Sleman, Daerah Istimewa Yogyakarta. Kegiatan pendampingan akan lebih difokuskan pada dua wilayah dusun, yaitu Dusun Kembang dan Dusun Pojok.

Kegiatan pendampingan dilakukan dengan berbagai metode diantaranya: seosialisasi, coaching, supervisi dan training atau workshop. Selain itu dalam pendampingan diadakan juga pengembangan atau pembangunan fasilitas diantaranya fasilitas cuci tangan dan poster-poster terkait CHSE. Todal dana pendampingan sebesar Rp. 19.230.000 yang berasal dari dana internal perguruang tinggi, dan dana bantuan dari Kementrian Pariwisata dan Ekonomi Kreatif. Program pendampingan juga didukung CSR dari Hotel Royal Ambarukmo. Jadwal pelaksanaan kegiatan seperti dijelaskan dalam tabel berikut:

Tabel 1. Jadwal Kegiatan Pendampingan Desa Wisata Garongan

\begin{tabular}{|c|c|c|}
\hline NO & TANGGAL & KEGIATAN \\
\hline 1 & 3 Februari 2020 & $\begin{array}{l}\text { Penandatanganan MOU Pendampingan Desa Wisata (Pemerintah Desa Wonokerto, } \\
\text { Desa Wisata Garongan dan STP AMPTA) }\end{array}$ \\
\hline 2 & 5-12 Februari 2020 & Sosialisasi Program Pendampingan ke PT (Kemenparekraf) \\
\hline 3 & 20 Februari 2020 & Pengumpulan Proposal Program Pendampingan \\
\hline 4 & 27 Februari 2020 & Penandatanganan PKS (Kemenpar - Perguruan Tinggi $(P T)$ \\
\hline 6 & & Pelaksanaan Training of Trainer (TOT) oleh Kemenparekraf \\
\hline 7 & 29 Agustus 2020 & Survei Potensi Wisata dan Homestay \\
\hline 8 & 10 Oktober 2020 & Pelatihan Standar Tata Kelola Homestay \\
\hline & & Pelatihan $C H S E$ \\
\hline 9 & 12 Oktober 2020 & Pelatihan Tata Kelola Desa Wisata dan Sapta Pesona \\
\hline 10 & 17 Oktober 2020 & Pelatihan Pengembangan Produk Wisata: Exploring Packaging Presentation (EPP) \\
\hline \multirow{4}{*}{11} & \multirow{4}{*}{20 Oktober 2020} & Pelatihan Kepemanduan Wisata \\
\hline & & Palatihan Pelayanan Prima \\
\hline & & Pelatihan Pengelolaan Keuangan Desa Wisata \\
\hline & & Pembuatan SOP dan Video Simulasi $C H S E$ \\
\hline
\end{tabular}


Sasaran dan penerima manfaat dari program pendampingan desa wisata adalah seluruh pelaku pariwisata di Desa Wisata Garongan sejumlah 25 orang yang terdiri dari Pengurus atau Pokdarwis Desa Wisata Garongan, masyarakat lokal, pemerintah lokal beserta pelaku usaha setempat.

\section{Hasil dan Pembahasan}

\section{Bimbingan Teknis Pendampingan Desa Wisata}

Kegiatan Bimtek Pendampingan Desa Wisata Regional 1B (Jawa) telah sukses dilaksanakan oleh Sekolah Tinggi Pariwisata AMPTA Yogyakarta (STP AMPTA)difasilitasi Kementrian Pariwisata dan Ekonomi Kreatif (Kemenparekraf)/Badan Pariwisata dan Ekonomi Kreatif. Adapun peserta Bimtek merupakan pelaku wisata di Desa Wisata Garongan yang merupakan mitra program pendampingan.

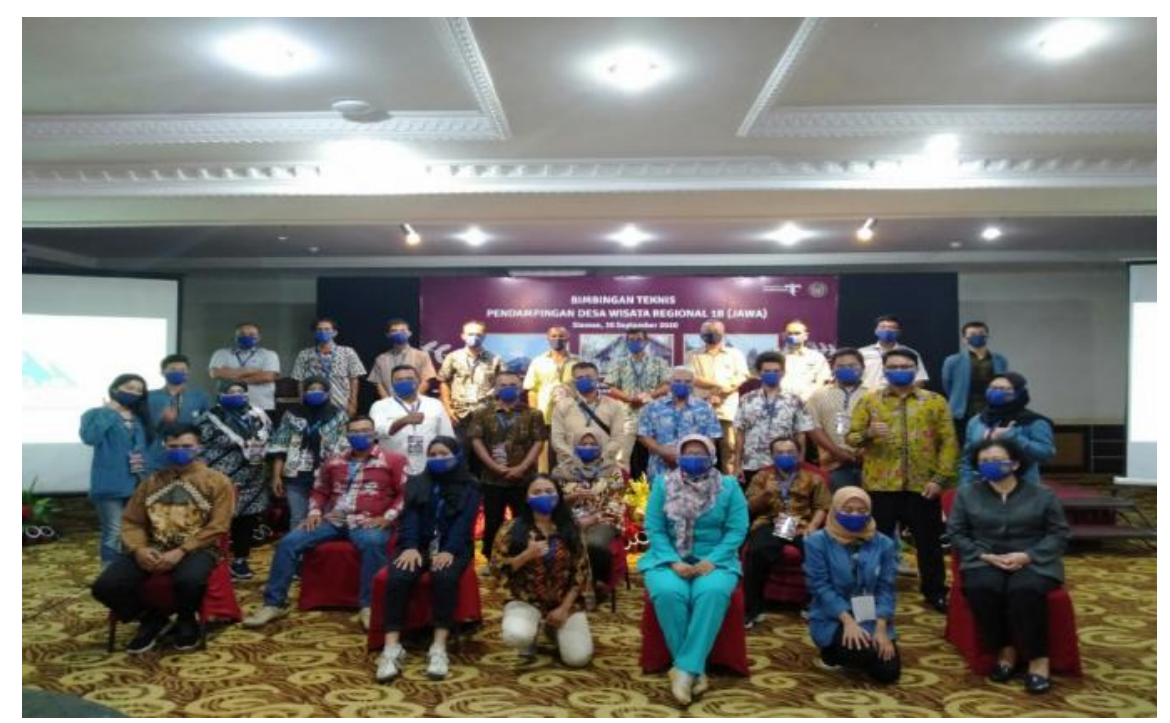

Gambar 1. Dokumentasi Bimtek Pendampingan Desa Wisata oleh STP AMPTA

Bimtek pendampingan desa wisata tersebut dilaksanakan pada tanggal 30 September 2020 di The Rich Hotel Yogyakarta. Acara ini dimulai sejak pukul 08.00 sampai dengan 17.00 WIB. Pemateri utama pada acara tersebut adalah tim trainer dari Sekolah Tinggi Pariwisata AMPTA Yogyakarta. Adapun yang hadir sebagai pemateri utama dalam bimtek tersebut adalah Bapak Hary Hermawan, S.Par., M.M selaku ketua tim tainer pendampingan Desa Wisata Garongan; Bapak Hermawan Prasetyanto, S.Sos., M.M selaku anggota; Ibu Iputu Hardani Hesti Duari, S.ST., M.Mselaku anggota; dan Ibu Angela Ariani, S.H., M.Mselaku anggota. Adapun moderator acara adalah Bapak Arif Dwi Saputra, S.S., M.M yang merupakan Ketua Program Studi Pariwisata Sekolah Tinggi Pariwisata AMPTA Yogyakarta.

Secara formal kegiatan Bimtek Pendampingan Desa Wisata ini merupakan kegiatan awal dari keseluruhan rangkaian program kerjasama pendampingan desa wisata oleh Sekolah Tinggi Pariwisata AMPTA dan Kemenparekraf. Dalam kesempatan ini disampaikan uraian teknis terkait program pendampingan.

Selain itu, dikenalkan juga materi-materi pariwisata yang sedang menjadi fokus isu Kemenparekraf pada saat ini, khususnya terkait adanya pandemi Covid-19. Adapun materi-materi yang dimaksud meliputi: Penerapan Cleanliness, Health, Safety and Enviromental Suistainability (CHSE); Penerapan Sapta Pesona; Pelayanan Prima; dan Pengembangan Produk Wisata: Exploring, Packaging, Presentation (EPP). 
Cleanliness, Health, Safety and Enviromental Suistainability (CHSE)merupakan hal yang saat ini mendesak untuk segera diterapkan di desa wisata guna menyambut peluang parwisisata di saat Adaptasi Kebiasaan Baru (AKB) dahulu populer dengan istilah new normal. Hal ini penting untuk dilakukan mengingat pada saat ini preferensi wisatawan cukup berbeda dalam mencari tempat wisata. Saat pandemi ini wsiatawan cenderung mencari lokasi wisata yang dianggap aman dan bebas dari Covid-19, tentunya dibuktikan dari adanya penerapat protokol kesehatan CHSE di tempat wisata, tidak terkecuali di desa wisata. Hal ini berbading terbalik dengan pengelola desa wisata, yang mayoritas merupakan masyarakat yang awam dengan dunia kesehatan.

Oleh karena itu, sebagai langkah awal perlu diberikan pemahaman terkait dengan penerapan protokol kesehatan, yang saat ini telah dirumuskan pemerintah melalui pedoman CHSE. Dalam kesempatan tersebut, Bapak Hermawan Prasetyanto, S.Sos., M.M menjadi pemateri CHSE sekaligus sebagai pembuka sesi presentasi.

Selanjutnya, Sapta Pesona dan Pelayanan Prima merupakan isu yang populer. Akan tetapi, kedua isu diatas masih terus menjadi isu yang menjadi perhatian dalam setiap kegiatan Bimtek Desa Wisata. Mengingat fakta di lapangan melalui berbagai sumber media berita masih sering ditemui berita terkait adanya komplain wisatawan terhadap pelayanan wisata yang ada di suatu destinasi. Sebagai solusi, peserta Bimtek diberikan materi terkait Sapta Pesona dan Pelayanan Prima yang di sajikan oleh Bapak Hary Hermawan, S.Par., M.M sebagai presenter kedua.

Pada sesi penutup, peserta Bimtek diberikan materi Pengembangan Produk Wisata: Exploring, Packaging, Presentation (EPP) oleh kedua narasumber yaitu Ibu Iputu Hardani Hesti Duari, S.ST., M.Mdan Ibu Angela Ariani, S.H., M.M. pada sesi ini diberikan sekilas tentang tata cara penyusunan paket wisata, namun pada sesi ini narasumber dan peserta lebih fokus untuk diskusi menggali berbagai problematika pengelolaan pariwisata di Desa Wisata Garongan, khususnya terkait produk wisata dan paket wisata.

Keseluruhan materi pada bimtek tersebut telah dikembangkan menjadi berbagai program pelatihan (workshop) yang lebih detail dan rinci serta menyesuaikan kebutuhan nyata di Desa Wisata Garongan. Selain program pelatihan, dari hasil bimtek ini tim trainer/pendamping juga menjadi fasilitator dalam mewujudkan berbagai program desa wisata.

\section{Pendampingan Pelayanan Prima}

Kepuasan merupakan perasaan senang atau kecewa seseorang yang muncul setelah membandingkan antara persepsi atau kesannya terhadap kinerja suatu produk dan harapan-harapannya dengan pengalaman nyata yang diterima. Dalam konteks pariwisata, kepuasan wisatawan dapat disebabkan oleh kesesuaian harapan wisatawan sebelumnya terhadap berbagai atribut yang melekat pada produk destinasi wisata dengan kondisi nyata yang diperoleh wisatawan.

Kepuasan wisatawan yang telah diperoleh selama menikmati destinasi merupakan kondisi yang sangat menentukan apakah wisatawan akan menjadi loyal terhadap destinasi atau tidak. Pelanggan yang merasa puas terhadap destinasi wisata umumnya akan menjadi pelanggan yang terus meners mengunjunginya (Gendro, 2019). Sebaliknya wisatawan yang tidak puas akan berhenti membeli, atau mengunjungi destinasi (Wallin Andreassen \& Lindestad, 1998). Kepuasan juga akan turut menentukan, apakah wisatawan akan merekomendasikan destinasi yang pernah dikunjunginya kepada orang lain atau tidak. Jika wisatawan puas ada kemungkinan untuk meberikan rekomendasi. Namun sebaliknya, jika wisatawan tidak puas cenderung akan memberikan rekomendasi yang negatif. Salah satu upaya menciptakan pengalaman wisata yang memuaskan dapat dilakukan dengan cara mewujudkan pelayanan prima.

Daya tarik wisata merupakan faktor kunci yang paling menentukan minat wisatawan untuk mengunjungi destinasi, tidak terkecuali adalah desa wisata (Basiya \& Rozak, 2012); (Sopyan \& Widiyanto, 2015); dan (Nasution et al., 2009). Namun, tanpa adanya pelayanan yang memuaskan yang disertai dengan keramah-tamahan (hospitality) maka destinasi wisata dapat diibaratkan sebagai raga tanpa jiwa.

Dalam bisnis pariwisata, pelayanan haruslah menjadi dasar dan motivasi utama dari usaha yang dijalankan. Semangat melayani dengan mengutamakan kebutuhan pelanggan harus dimiliki oleh 
seluruh jajaran staf tanpa terkecuali, baik itu top manajer maupun staf operasional, sesuai porsi dan uraian tugas masing-masing (Hermawan et al., 2018).

Pelayanan adalah kegiatan yang dapat diidentifikasi, serta bersifat sebagai media penghubung antara satu pihak dengan pihak lain dengan maksud dan tujuan tertentu. Sedangkan pelayanan prima dapat dimaknai sebagai pelayanan yang terbaik atau pelayanan berkualitas. Pelayanan terbaik merupakan upaya optimal yang dapat diupayakan pengelola wisata untuk mewujudkan pengalaman berwisata yang memuaskan.

Kualitas pelayanan merupakan ukuran seberapa bagus tingkatan layanan yang diberikan mampu sesuai dengan ekspektasi pelanggan artinya kualitas pelayanan artinya kebutuhan dan keinginan tamu atau pengunjung yang di tentukan perusahaan.

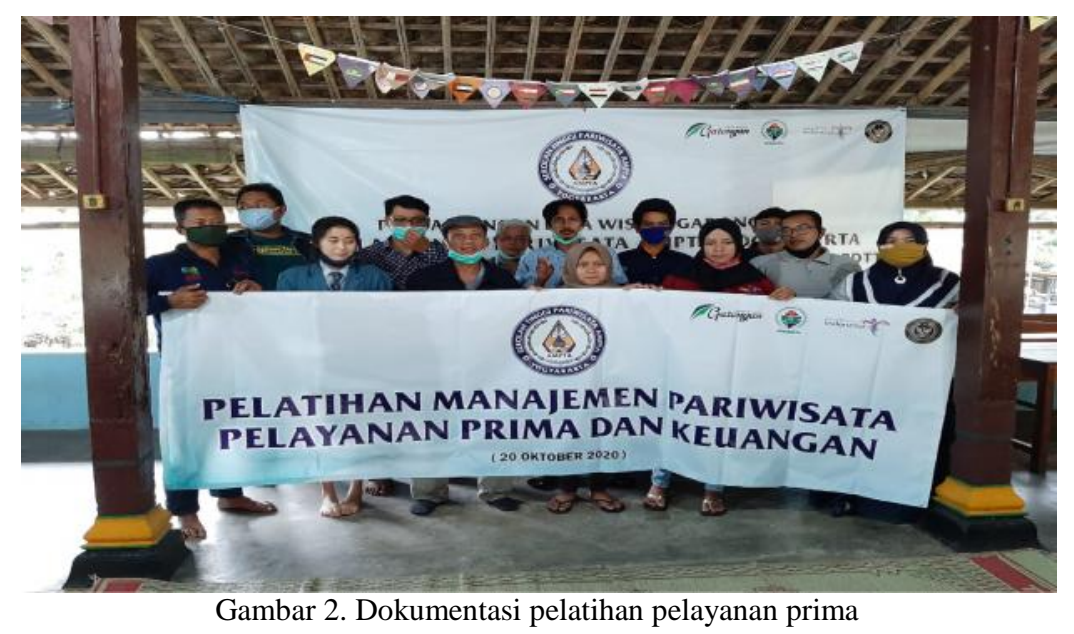

Tabel 2. Hasil dan Capaian Pendampingan Pelayanan Prima

\begin{tabular}{|c|c|c|}
\hline No & Kondisi Sebelum Pendampingan & Kondisi Setelah Pendampingan \\
\hline 1 & Seluruh peserta memiliki pembawaan yang ramah & Seluruh peserta memiliki pembawaan yang ramah \\
\hline 2 & $\begin{array}{l}\text { Peserta belum memahami konsep } 5 \text { dimensi } \\
\text { pelayanan prima. Walaupun saat diuji roleplay } \\
\text { sudah mampu mempraktikan dengan baik }\end{array}$ & $\begin{array}{l}\text { Peserta mampu memahami dengan baik konsep } 5 \\
\text { dimensi pelayanan prima sebagai dogma dalam } \\
\text { pelayanan pariwisata. } \\
\text { Peserta mampu mempraktikan dengan baik }\end{array}$ \\
\hline 3 & $\begin{array}{l}\text { Peserta belum memiliki pemahaman yang baik } \\
\text { terkait konskuensi pelayanan: wisatawan puas/tidak } \\
\text { puas. Beserta dampaknya terhadap bisnis desa } \\
\text { wisata }\end{array}$ & $\begin{array}{l}\text { Adanya peningkatan pemahaman terkait costomer } \\
\text { oriented dan konsekuensi pelayanan }\end{array}$ \\
\hline 4 & $\begin{array}{l}\text { Peserta sebagian besar sudah memahami konsep } \\
\text { sapta pesona dan mampu menerapkan }\end{array}$ & Sapta pesona sudah dijalankan \\
\hline 5 & $\begin{array}{l}\text { Belum adanya guest comment untuk media } \\
\text { menyampaikan keluhan pelanggan }\end{array}$ & Sudah tersedia \\
\hline
\end{tabular}

Pengelola Desa Wisata Garongan telah diberikan pelatihan Sapta Pesona dan Pelayanan Prima. Sebagai penanggungjawab program adalah Bapak Hary Hermawan, S.Par., M.M. Sapta pesona adalah 7 (tujuh) unsur pesona yang harus diwujudkan bagi terciptanya lingkungan yang kondusif dan ideal bagi berkembangnya kegiatan kepariwisataan di suatu tempat yang mendorong tumbuhnya minat wisatawan untuk berkunjung. Ketujuh unsur sapta pesona yang dimaksud di atas adalah: aman; tertib; bersih; sejuk; indah; ramah tamah; dan kenangan

\section{Pendampingan Penerapan Cleanlinness, Health, Safety and Enviroment Suistainability (CHSE)}

Sebelum kegiatan pelatihan dijalankan, sebelumnya tim trainner telah beberapa kali melakukan survei lapangan dan sekaligus melakukan wawancara kepada para pengurus dan pelaku wisata khususnya terkait penerapan Protokol Covid 19 CHSE pada Adaptasi Kebiasaan Baru (AKB). 


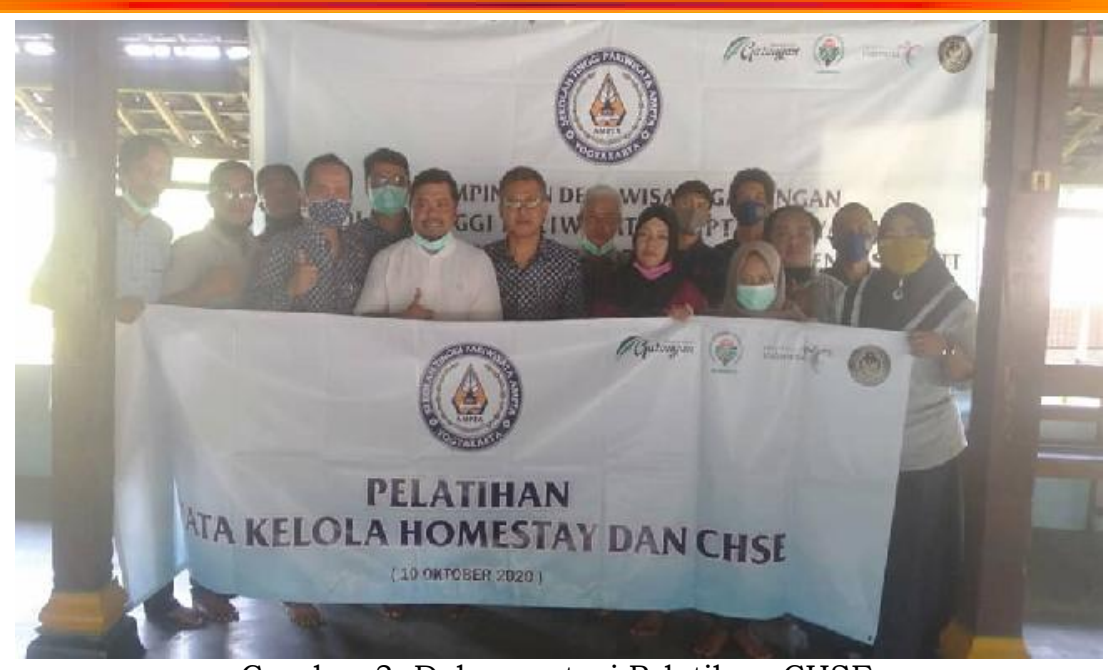

Gambar 3. Dokumentasi Pelatihan CHSE

Sehingga mendapatkan data-data yang komprehensif terkait dengan kondisi protokol kesehatan CHSE saat ini, dan kemudian data data tersebut kita gunakan untuk menyusun rencana - rencana kegiatan sekaligus untuk menyusun materi - materi pelatihan yang akan disampaikan kepada para pengurus dan masyarakat yang etrlibat secara langsung dalam kegitan Desa Wisata Garongan dari beberapa unsur yang ada.

Hasilnya bahwa perlu dilakukan Sosialisasi dalam hal penerapan CHSE dikawasan Desa Wisata Garongan sehingga dapat mebantu terlaksananya penerapan Protokol Covid 19 pada Adaptasi Kebiasaan Baru (AKB), sebagai rukujan adalah Pedoman CHSE Destinasi: https://chse.kemenparekraf.go.id/themes/chse/assets/documents/Handbook_Destination.pdf

Perlu dilakukan Sosialisasi kepada para pelaku wisata mengenai : (1) Prinsip tata kelola CHSE Sesuai dengan Buku Pedoman CHSE; (2) Fasilitas-fasilitas yang mesti disiapkan / harus ada; (3) Manajemen pengelolaanya, termasuk SOP.

Pada lingkup ini, trainner lebih berperan sebagai konsultan dan fasilitator yang memberikan anjuran dan jejaring untuk menyiapkan berbagai fasilitas pendukung penerapan CHSE. Hasil pendampingan menunjukan bahwa terdapat perbedaan yang sangat jelas, pada saat sebelum dan setelah pendampingan.

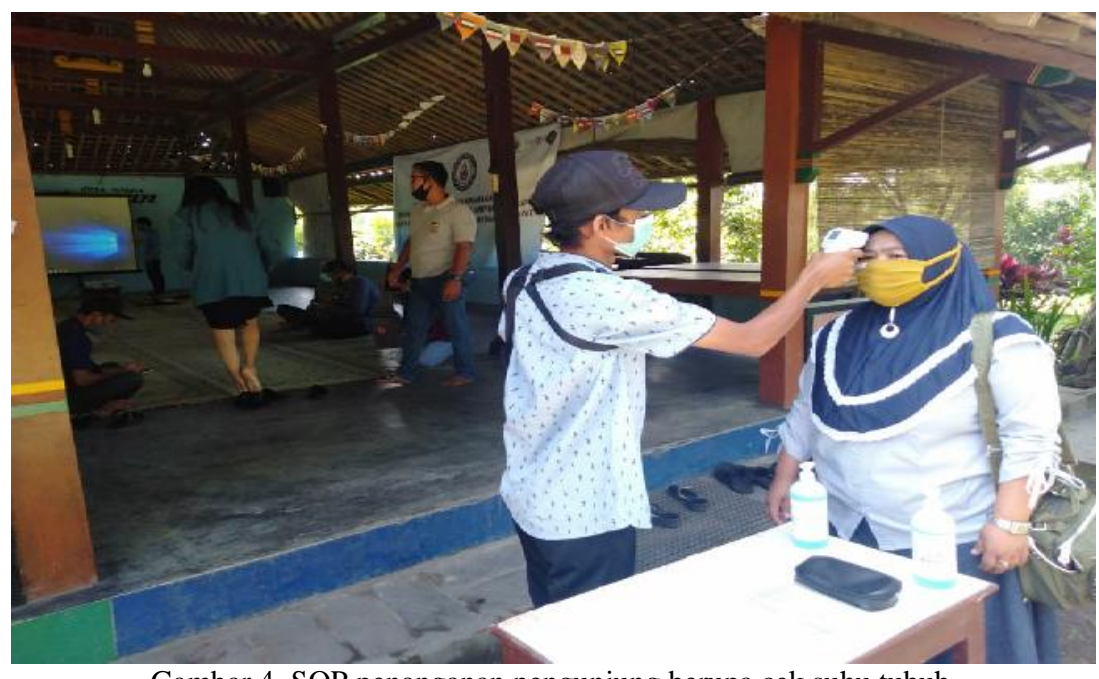

Gambar 4. SOP penanganan pengunjung berupa cek suhu tubuh

Rekomendasi Kegiatan Selanjutnya dari trainner adalah Melakukan pendampingan dalam pelaksanaan CHSE di Desa Wisata Garongan serta memberikan sumbangan masukan dan saran serta fasilitas (bila memungkinkan) dalam proses persiapan dan pelaksanaanya. 
Tabel 3. Hasil dan Capaian Pendampingan Penerapan CHSE Desa Wisata

\begin{tabular}{|c|c|c|c|}
\hline No & $\begin{array}{c}\text { Sebelum Pendampingan } \\
\end{array}$ & Setelah Pendampingan & Progres \\
\hline 1 & $\begin{array}{l}\text { Belum tersedia wastafel dan sabun untuk cuci } \\
\text { tangan }\end{array}$ & $\begin{array}{l}\text { Tersedia wastafel dan sabun untuk cuci } \\
\text { tangan di berbagai titik }\end{array}$ & Terlaksana \\
\hline 2 & $\begin{array}{l}\text { Belum tersedia handsanitizer dan disinfektan di } \\
\text { berbagai titik }\end{array}$ & $\begin{array}{l}\text { Sudah tersedia handsanitizer dan } \\
\text { disinfektan di berbagai titik }\end{array}$ & Terlaksana \\
\hline 3 & $\begin{array}{ll}\text { Belum ada SOP penanganan pengunjung } \\
\text { - } & \text { Cek suhu dengan Termo gun } \\
- & \text { Anjuran jaga jarak } \\
- & \text { Pemakian masker } \\
- & \text { Prosedur penanganan jika terdapat } \\
& \text { wisatawan dengan suhu diatas } 27 \mathrm{C} \\
\text { - } & \text { Dsb }\end{array}$ & Sudah tersedia SOP & Terlaksana \\
\hline 4 & $\begin{array}{l}\text { Belum tersedia papan petunjuk terkait penerapan } \\
\text { protokol Covid-19 }\end{array}$ & Sedang dalam proses pengerjaan & Dalam proses \\
\hline
\end{tabular}

\section{Pendampingan Pengelolaan Homestay}

Sebelum kegiatan pelatihan dijalankan, sebelumnya tim trainner telah beberapa kali melakukan survei lapangan dan sekaligus melakukan wawancara kepada para pengurus dan pelaku wisata khususnya di bidang homestay. Sehingga mendapatkan data-data yang komprehensif terkait dengan pengelolaan saat ini, dan kemudian data data tersebut digunakan untuk menyusun rencana - rencana kegiatan sekaligus untuk menyusun materi - materi pelatihan yang disampaikan kepada para pengurus dan masyarakat yang terlibat secara langsung dalam kegitan Desa Wisata Garongan dari beberapa unsur yang ada.

Pelatihan diawali dengan penyampaian gagasan kepada partisipan yaitu masyarakat serta tokohtokoh pengambil kebijakan di Desa Wisata Garongan dengan bentuk kegiatan diskusi panel dengan tata cara sebagai berikut: (2) Penyampaian materi terkait perbedaan mendasar pengelolaan Homestay dan hotel termasuk hambatan dan solusi dalam pelayanan jasa penginapan; (2) Penyampaian materi terkait pedoman penyelenggaraan homestay; (3) Mampu menerapkan prosedur CHSE pada bidang usaha homestay.

Capaian yang diharapakan dari program pelatihan ini berupa peningkatan pengetahuan masyarakat tentang standar pengelolaan homestay serta pengetahuan tentang segala hal yang harus dipersiapkan dalam mengoptimalkan usaha jasa homestay. Hasilnya bahwa perlu dilakukan Sosialisasi dalam hal penerapan pengelolaan standar usaha homestay di Desa Wisata Garongan, sehingga dapat mebantu pelaku usaha homestay dalam mewujudkan produk homestay yang terstandar dan berkualitas. Perlu dilakukan sosialisasi standar homestay dan CHSE kepada para pelaku usaha homestay mengenai (1) Prinsip tata kelolanya; (2) Fasilitas fasilitas standar yang mesti disiapkan atau harus ada; (3) Manajemen pengelolaanya.

Melakukan penyuluhan / pelatihan \& edukasi kepada beberapa person yang dipilih oleh pengurus Desa Wisata dalam 2 (dua) hal, yaitu Clean Health Safety andEnvironment Suistanability (CHSE) homestay dan Standar Tata kelola homestay

Rekomendasi Kegiatan Selanjutnya yaitu: (1) Melakukan pendampingan dalam pelaksanaan usaha homestay di Desa Wisata Garongan serta memberikan sumbangan masukan dan saran serta fasilitas (bila memungkinkan) dalam proses persiapan dan pelaksanaanya. Diketahui bahwa beberapa homestay belum memiliki papan nama usaha; (2) Melakukan pendampingan dalam pelaksanaan sistem tata kelola homestaydi Desa Wisata Garongan serta memberikan sumbangan masukan dan saran serta fasilitas (bila memungkinkan) dalam proses persiapan dan pelaksanaanya; (3) Sudah terdapat beberapa pengurus yang berani maju untuk uji sertifikasi profesi pengelola homestay dan akhirnya dinyatakan kompeten dalam memberikan pelayanan usaha homestay. 
Tabel 4. Hasil dan Capaian Pendampingan Pengelolaan Homestay

\begin{tabular}{|c|c|c|}
\hline No & Kondisi Sebelum Pendampingan & Kondisi Setelah Pendampingan \\
\hline 1 & $\begin{array}{l}\text { Pengelola belum memiliki pemahaman yang baik } \\
\text { dalam mengelola homestay termasuk: } \\
\text { memberikan pelayanan akomodasi, dan juga } \\
\text { standar kelayakan fasilitas homestay }\end{array}$ & Pemahaman peserta meningkat \\
\hline 2 & $\begin{array}{l}\text { Masih terjadi kesalahan pemahaman bahwa } \\
\text { pelayanan homestay harus mewah seperti hotel, } \\
\text { menjadikan masyarakat kurang percaya diri } \\
\text { untuk menjadikan rumahnya sebagai homestay }\end{array}$ & $\begin{array}{l}\text { Pemahaman peserta meningkat, homestay } \\
\text { adalah rumah warga yang ditingkatkan } \\
\text { fungsinya sebagai tempat tinggal wisatawan. } \\
\text { standar homestay berbeda dengan standar hotel. }\end{array}$ \\
\hline 3 & $\begin{array}{l}\text { Belum terdapat kespakatan pemahaman yang } \\
\text { sama antara pengelola desa wisata dengan } \\
\text { pemilik homestay terkait hewan peliharaan }\end{array}$ & $\begin{array}{l}\text { Terjadi kesamaan pemahaman, pengelola } \\
\text { homstay harus merelakan hewan peliharaan } \\
\text { untuk dipisahkan saat ada tamu }\end{array}$ \\
\hline 4 & $\begin{array}{l}\text { Fasilitas homestay di Desa Wisata Garongan } \\
\text { pada dasarnya sudah baik. }\end{array}$ & $\begin{array}{l}\text { Sudah tersedia catatan administratif/sudah } \\
\text { disiapkan. }\end{array}$ \\
\hline & $\begin{array}{l}\text { Kamar bersih, toilet bersih, sumber air melimpah. } \\
\text { Namun ada beberapa kekurangan diantaranya: } \\
\text { belum semua kamar memiliki lemari, belum } \\
\text { terdapat papan nama homstay, belum memiliki } \\
\text { laporan administrasi yang baik }\end{array}$ & $\begin{array}{l}\text { Peserta memiliki komitmen untuk } \\
\text { meningkatkan kualitas homestaynya }\end{array}$ \\
\hline 5 & Beberapa kamar belum rapi dan belum di cat & Sudah dirapikan dengan cat yang menarik \\
\hline
\end{tabular}

\section{Pendampingan Pengembangan Produk Wisata: Exploring, Packaging, Presentation (EPP)}

Pada hari Selasa tanggal 17 Oktober 2020 telah dilaksanakan program nyata pedampingan masyarakat desa wisata, berupa pelatihan pengembangan produk wisata, khususnya paket wisata di desa wisata Garongan (Surat Tugas Nomor: 397c/LPPM-AMPTA/X/2020), dan dihadiri oleh orang, sebagai wujud nyata pendampingan di desa wisata dengan tujuan memberdayakan masyarakat di desa wisata Garongan.

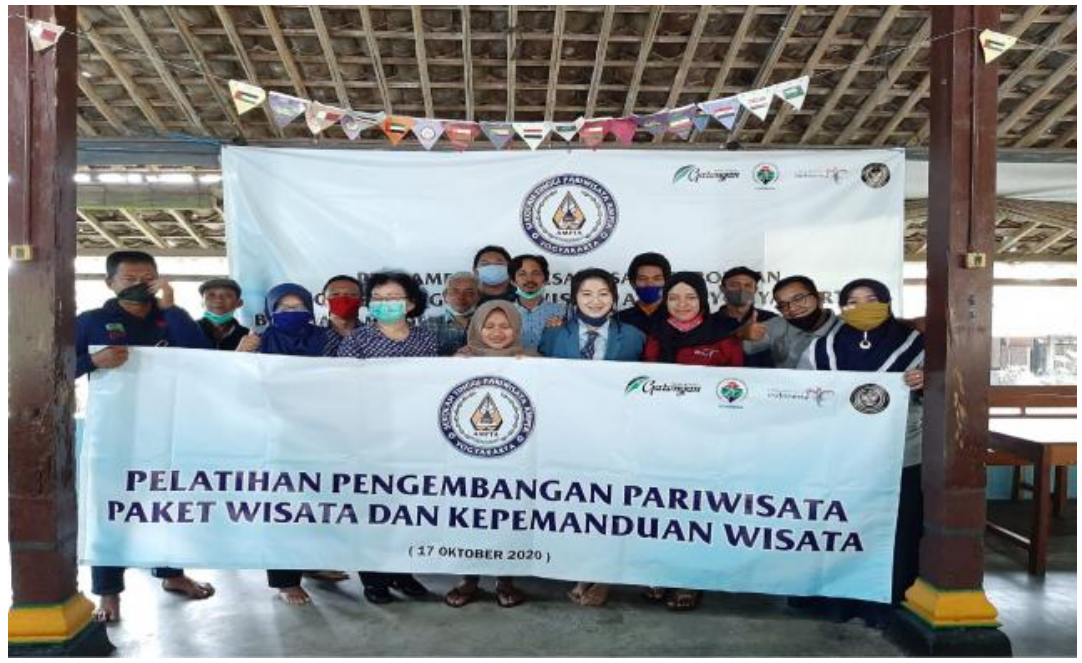

Gambar 5. Dokumentasi Pelatihan Pengembangan Pariwisata Paket Wisata dan Kepemanduan

Kata kunci program pendampingan ini adalah "pemberdayaan masyarakat", dalam bentuk pelatihan berorientasi pada kondisi terkini desa wisata dan partisipasi aktif masyasrakat sangat dibutuhkan. Sehingga terwujud kebersamaan gerak langkah antara masyarakat dengan pendamping.

Pada awal pelatihan, pendamping mengajak peseta melakukan brain storming, dengan maksud mendengarkan permasalahan dari peserta pelatihan serta pemberian informasi tentang paket kegiatan yang selama ini sudah ada dan dijual kepada tamu yang berkunjung ke desa wisata Garongan, dilanjutkan dengan memberikan tanggapan awal dan alternative solusi tepat sasaran, sebagai bentuk motivasi kepada masyarakat agar bersemangan dalam mencapai tujuan yang telah ditetapkan secar bersama-sama. Ada beberapa yang mengemuka: (1) Mengenai jumlah peserta paket yang selama ini secara grup, untuk dialihkan menjadi peserta individu (menyesuaikan permintaan pasar di masa/pasca pandemic covid-19); (2) Terkait juga dengan bagaimana cara menghitung dan menentukan harga paket; (3) Variasi konten paket wisata: berupa kemasan beraneka ragam fasilitas dan jasa; (4) Ada potensi produk yang belum sempat dikemas dalam paket, yaitu: wisata kebun salak serta pelatihan 
budidaya pohon salak (cara menanam, memelihara dan merawat pohon dan kebunnya) dengan segala atribut yang bersifat komesaial.

Pemberian informasi tentang paket-paket kegiatan yang selama ini sudah ada dan dijual di desa wisata Garongan (seperti yang ditunjukkan melalui booklet yang sudah dibuat), yang bisa dikemas kembali sesuai dengan permintaan pasar. Ada beberapa di antara peserta pelatihan yang menguasai dan memahami perihal pengemasan produk potensial yang mereka miliki, bahkan sekaligus sebagai pelaku kegiatan yang berinteraksi langsung dengan pengunjung.

Terdapat 4 (empat) tahapan yang telah dilakukan dalam pelatihan ini: Tahap Pertama Exploring, dalam mengembangkan suatu desa wisata, maka diperlukan krearivitas tanpa batas namun tetap mengutamakan kearifan lokal sebagai point interest untuk layak dikunjungi oleh wisatawan. Desa wisata Garongan merupakn salah satu desa wisata yang menjadi prioritas kemedes untuk dikembangkan menjadi salah satu obyek wisata unggulan di Kabupaten Sleman. Beberapa hal saat ini perlu dibenahi untuk bisa menjadi desa wiasata yang dikenal dan dikunjungi. Salah satu kegiaatan pendampingan desa wisata yaitu pelatihan menyusun paket wisata. Paket wisata yang ada dan telah tersaji indah namun belum menyeluruh sehingga masih diperlukan pembenahan. Salah satu tahap untuk pembenahan yaitu dengan melakukan Exploring. Exploring ini merupakan tahap awal untuk proses identifikasi permasalahan dan pencarian solusi yang berkearifan lokal. Masyarakat desa wisata Garongan, sebagai peserta pelatihan, bersama dengan pendamping menemu-kenali dan menginventaris beragam potensi jenis produk yang mereka miliki, bisa dilihat pada tabel berikut:

\begin{tabular}{|c|c|c|}
\hline Produk inti & Produk actual & Produk tambahan \\
\hline Keunikan & $\begin{array}{l}\text { Dikemas dengan beragam varian paket } \\
\text { wisata yang masih sangat minimalis }\end{array}$ & Pemanduan wisata \\
\hline Keunggulan & $\begin{array}{l}\text { Desa wisata dengan kearifan lokal dan } \\
\text { pemandangan yang masih alami dan } \\
\text { pedesaan }\end{array}$ & Sovenir dan produk lokal \\
\hline $\begin{array}{l}\text { Sdm } \\
\text { Sebagai kunci }\end{array}$ & $\begin{array}{l}\text { Pokdarwis dan struktur organisasi yang } \\
\text { masih sederhana }\end{array}$ & $\begin{array}{l}\text { Pengelola sekaligus pemandu } \\
\text { wisata dengan beragam } \\
\text { kemampuan berbahasa asing }\end{array}$ \\
\hline
\end{tabular}

Tabel 6. Ketersediaan jenis produk di desa wisata Garongan

\begin{tabular}{|c|c|c|c|}
\hline No & Jenis Produk & Ketersediaan & Keterangan \\
\hline 1 & Fasilitas & $\begin{array}{l}\text { - Camping ground dengan peralatan gamming } \\
\text { - Kolam ikan } \\
\text { - Penginapan rumah tinggal (homestay) } \\
\text { - Perkebunan salak (dikelola oleh kelompok } \\
\text { tani) }\end{array}$ & $\begin{array}{l}\text { - Terrawat bagus } \\
\text { - Terrawat bagus } \\
\text { - Terrawat bersih } \\
\text { - Terrawat bersih }\end{array}$ \\
\hline 2 & $\begin{array}{l}\text { Daya Tarik } \\
\text { Wisata }\end{array}$ & $\begin{array}{l}\text { - Patung Jaka Garong (dengan storry telling- } \\
\text { nya) } \\
\text { - Keindahan alam perdesaan } \\
\text { - Udara sejuk } \\
\text { - Lingkungan pepohonan rindang } \\
\text { - Spot berfoto yang unik dan instagrammable } \\
\text { - Ada makanan khas, gantungan kunci } \\
\text { - Pelatihan budi daya tanaman salak }\end{array}$ & $\begin{array}{l}\text { - Terrawat dan iconic } \\
\text { - Alami } \\
\text { - Alami } \\
\text { - Terrawat } \\
\text { - Terrawat } \\
\text { - Belum digarap baik } \\
\text { - to learn something }\end{array}$ \\
\hline 3 & SDM & $\begin{array}{l}\text { - Ramah, team work (dalam organisasi } \\
\text { sederhana), } \\
\text { - Kompeten berbahasa asing (selain Inggris) } \\
\text { - Mengenal IT dengan baik ("digital platform") }\end{array}$ & $\begin{array}{l}\text { - Re-strukturisasi } \\
\text { - Pemanduan } 5 \text { bahasa } \\
\text { asing } \\
\text { - Media promosi }\end{array}$ \\
\hline 4 & Akses & $\begin{array}{l}\text { Memadahi, cukup mudah terjangkau } \\
\text { (accessable) }\end{array}$ & $\begin{array}{l}\text { Tidak bisa dijangkau } \\
\text { dengan kendaraan } \\
\text { umum }\end{array}$ \\
\hline 5 & $\begin{array}{l}\text { Aktivitas } \\
\text { (dilengkapi } \\
\text { asuransi) }\end{array}$ & $\begin{array}{l}\text { - Berkemah dan gamming } \\
\text { - Susur sungai } \\
\text { - Menyelenggarakan event di pendopo } \\
\text { - Memancing } \\
\text { - Memetik buah salak } \\
\text { - Berinteraksi dengan komunitas lokal }\end{array}$ & - Ada instruktur \\
\hline
\end{tabular}


1. Dari ketersediaan jenis produk yang dimiliki oleh desa wisata Garongan, dan sekaligus sebagai aset berkarakter kearifan local (local wisdom) dan yang harus dilestarikan oleh pengelola yang bertanggungjawab dan unggul, hendaknya bisa dikemas secara menarik (ditambah sentuhan aplikasi teknologi) untuk menjadi paket andalan yang memiliki keaslian, keunikan sehingga bisa bersaing dengan paket sejenis yang dijual oleh desa wisata lainnya.

2. Pengelola perlu meningkatkan/mengembangkan kerja sama dengan stakeholder pariwisata terkait ("pentahelix"), agar bisa memiliki jaringan/koneksi pemasaran lebih banyak, misalnya dengan ASITA (= asosiasi yang memayungi perusahaan Biro Perjalanan Wisata di Indonesia).

Dengan demikian, akhir tahap exploring ini adalah memahami, mengubah dan membentuk karakter pribadi dan produk yang unggul di Desa Wisata Garongan.

Tahap Kedua Packaging, setelah masyarakat desa wisata Garongan meyakini bahwa mereka menjadi sumber daya manusia yang memiliki karakter dan sekaligus memiliki produk yang unggul, maka pada tahap ini mereka perlu mengedukasi dan meningkatkan kompetensi mereka sebagai pengelola Desa Wisata Garongan yang berkarakter dan unggul juga. Produk wisata unggulan yang ada di desa wisata Garongan bisa dibaca pada tabel 2 berikut ini:

Tabel 7. Produk Unggulan di Desa Wisata Garongan

\begin{tabular}{|c|c|}
\hline No & $\begin{array}{l}\text { Jenis Produk Unggulan } \\
\end{array}$ \\
\hline 1 & $\begin{array}{l}\text { Icon Patung Jaka Garong: Jaka Garong Management menjadikan icon ini sebagai konten } \\
\text { materi pemanduan, yaitu berupa story telling yang menjelaskan tentang sejarah desa } \\
\text { mereka dinamakan desa wisata Garongan. Dan konten ini sekaligus sebagai daya tarik } \\
\text { wisata unik dan khas yang hanya bisa ditemui di desa wisata Garongan. }\end{array}$ \\
\hline 2 & $\begin{array}{l}\text { Pengembangan paket kegiatan berbasis edukasi: Pemanduan di desa wisata Garongan } \\
\text { dalam } 5 \text { bahasa asing (selain bahasa Inggris) sedang dirintis oleh masyarakat, yang nota } \\
\text { bene mereka pernah bekerja sebagai tenaga kerja Indonesia di beberapa negara asing } \\
\text { tersebut dan kompeten berbahasa asing, misal: Arab, Jepang, beberapa negara bagian di } \\
\text { Eropa); } \\
\text { Pengembangan paket kegiatan perikanan, dengan memanfaatkan kolam perikanan Mina } \\
\text { Taruna yang dikelola oleh kelompok peternak ikan, melalui special interest package } \\
\text { (dalam tahap rintisan): memancing dan sekaligus mengolah hasil pancingan; } \\
\text { Budidaya tanaman pohon salak, sekaligus belajar untuk berkebun tanaman salak }\end{array}$ \\
\hline 3 & $\begin{array}{l}\text { Camping Ground } \\
\text { Sudah menjadi paket kegiatan andalan di desa wisata Garongan.Mereka menyediakan } \\
\text { persewaan tenda dan instruktur yang kompeten. }\end{array}$ \\
\hline 4 & $\begin{array}{l}\text { Paket petik buah salak } \\
\text { Perlu ditegaskan ketentuan bagi peserta yang membeli paket ini, berpa hal } 2 \text { teknis selama } \\
\text { berada di kebun salak, termasuk durasi berada di kebun salak. }\end{array}$ \\
\hline 5 & $\begin{array}{l}\text { Treking Sungai } \\
\text { Melakukan treking sungai akan melatih kemampuan dalam salah satu kegiatan alam yang } \\
\text { benar2 alami. }\end{array}$ \\
\hline \multicolumn{2}{|r|}{$\begin{array}{l}\text { Catatan penting dari pendamping pada tahap exploring ini adalah: } \\
\text { 1. Dalam menyusun paket kegiatan ata pola perjalanan, hendaknya unik, asli dan tematik serta dengan penjelasan yang } \\
\text { rinci dan detail; } \\
\text { 2. Perhatikan adanya padu-padan antara tujuan bersenang-senang dengan tetap mengedepankan unsur ekonomi kreatif } \\
\text { masyarakat dan kearifan lokal dalam something to see, to do, to buy, to learn } \\
\text { 3. Dalam setiap kegiatan yang dilakukan pengunjung di desa wisata Garongan, hendaknya Jaka Garong Management } \\
\text { bisa mendokumentasikannya dalam video yang kemudian dikirimkan kepada tamu (sebagai "after sales service"). } \\
\text { Dengan demikian, akhir tahap packaging ini adalah melalui sumber daya manusia yang bertanggung jawab dan } \\
\text { kompeten bisa menghasilkan produk2 unggulan yang berkarakter unik, asli, khas sehingga bisa menjadikan satu } \\
\text { kesatuan dan sekaligus kekuatan desa wisata Garongan. }\end{array}$} \\
\hline
\end{tabular}

Setelah tahap exploring, maka tahap selanjutnya yaitu Packaging. Dalam tahap ini, sesuai dengan temuan yang ada dilapangan menunjukan bahwa potensi yang ada dibuat menjadi paket wisata yang variatif tanpa meninggalkan kearifan lokal pada desa wisata Garongan. Identifikasi potensi yang ada di Desa wisata Garongan.

Konsep Paket Wisata di Desa Wisata Garongan dengan mengambil salah satu poin of Interest yang ada yaitu dengan konsep pemanduan wisata. Konsep pemanduan wisat dengan mengambil nama dan sosok fenomenal di desa wisata Garongan yaitu Jaka Garong. 


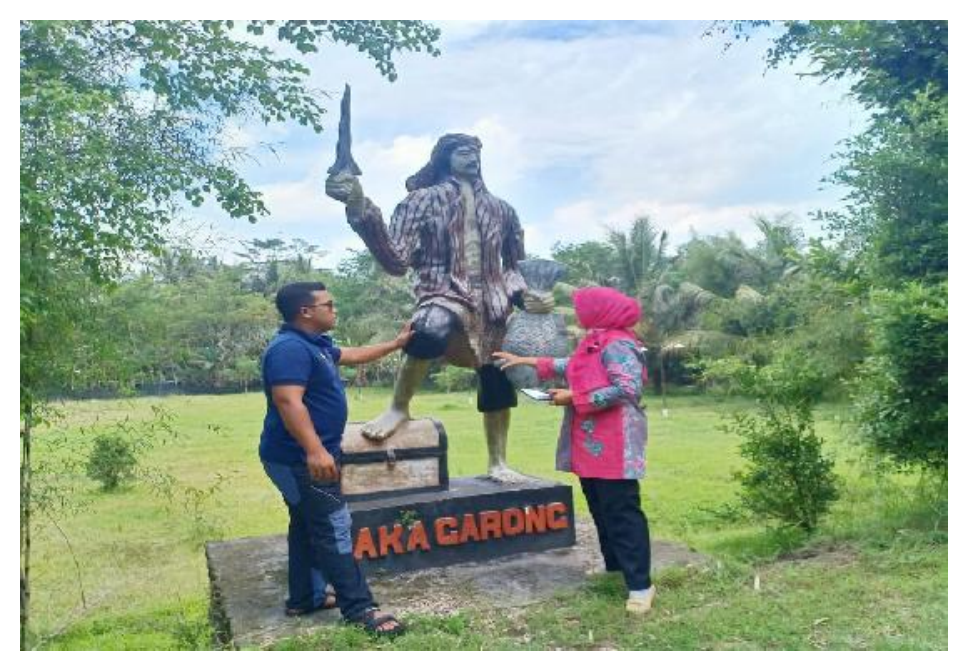

Gambar 6. Patung Jaka Garong sebagai ikon wisata

Jaka Garong ini menjadi sosok inspiratif yang memberikan nama Desa Wisata Garongan. Konsep Desa Wisata Garongan mengangkat tema pemanduan wisata tentang Jaka Garong.

Camping Ground menjadi salah satu paket wisata yang ditawarkan dalam desa wisata Garongan, hal ini dikarenakan luasnya lahan yang ada dan juga keindahan alam berupa pegunungan dan kesejukan udara yang ada di desa wisata Garongan. Jarak Desa wisata Jaka Garong atau Garongan ini dengan Gunung Merapikuranglebihadalah12kmdanmasihtergolongdalamtitikaman. Sehingga pada saat pagi hari jika tidak terlihat kabut, akan terlihat pemandangan yang sangat bagus. Selain itu Camping Ground ini terbagi menjadi 2 wilayah yaitu Jaka Garong I dan Jaka Garong 2. Jakagarong 1 terletak di sisi selatan dengan luas 2 hektar yang dapat di gunakan untuk kegiatan sekitar 350 peserta dengan kapasitas 50 tenda pramuka. Sedangkan Jakagarong 2 berada di sisi utara yang dapat di gunakan untuk kegiatan sekitar 200 peserta dengan kapasitas 30 tenda pramuka. Namun saat covid 19 ini, lahan camping lebih banyak digunakan untuk camping privat dan family

Kolam ikan Mina Taruna ini sangat unik karena air yang mengalir langsung dari mata air gunung merapi, sehingga ikannya sangat lincah. Dalam paket wisata di kolam ikan ini, desa wisata Garongan menawarkan paket wisata memancing, memberi makan ikan, menangkap ikan sampai dengan wisata edukatif yaitu tentang cara pembibitan ikan. Pola paket wisata edukatif ini akan dikembang dengan beberapa pengolahan produk olahan ikan yang secara variatif dan kekinian.

Paket wisata di desa wisata garongan ini juga menawarkan paket wisata edukatif yaitu berupa belajar berkebun salak, belajar lebih dekat mengenai cara penanaman salak, serta belajar untuk mengetahui cara memanen salak dengan benar sehingga tidak tertusuk duri. Dalam konsep pelatihan yang diberikan yaitu memberikan edukasi terhadap para pelaku wisata teruta,ma pada bagian paket wisata di perkebunan ini yaitu dengan durasi waktu dalam kebun itu sendiri karena durassi akan memberikan efektivitas waktu kunjungan dan waktu pembelajaran bagi wistatawan.

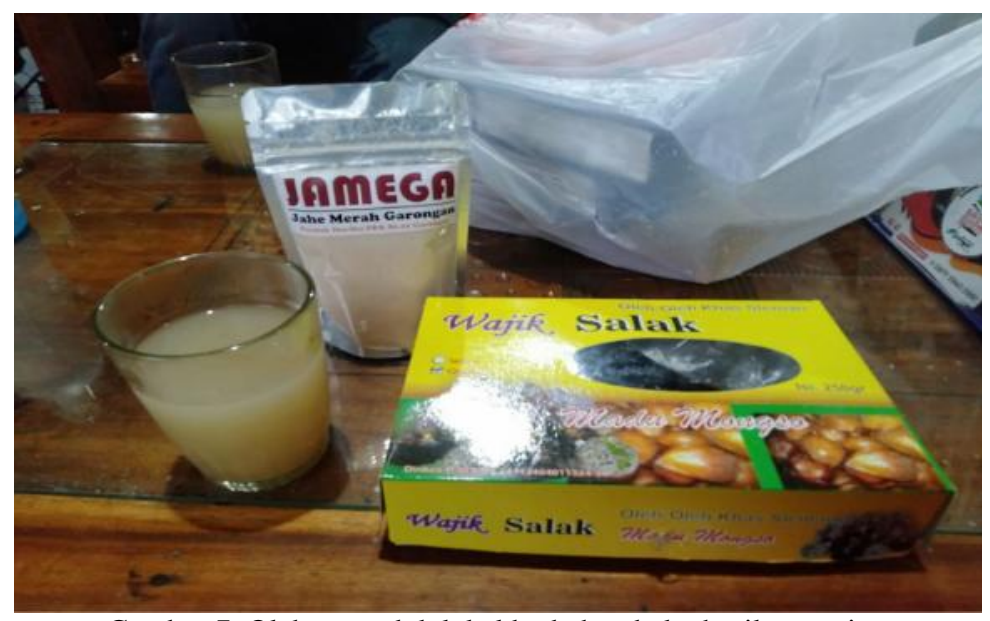

Gambar 7. Olahan produk lokal berbahan baku hasil pertanian 
Tahap Ketiga Presentation. Berdasarkan produk unggulan desa wisata Garongan pada tabel 2 tersebut, jelas pasar dominan pengunjung desa wisata itu adalah kelompok usia muda yang enerjik, penuh semangat, ingin menguji adrenalin dan kelompok pengunjung yang menginginkan kembali ke alam ("back-to-nature" market). Selama masa pandemi covid-19 ini serta pasca pandemi nanti, penting bagi Jaka Garong Management untuk melakukan ata mengerjakan pekerjaan rumah, yaitu memulihkan desa wisata Garongan sebagai tourist destination dan memulihkan pasar yang selama ini sudah berhasil dibidik. Paket Wisata Desa Wisata Jaka Garong mengambil komsep sejarah Jaka Garong. Berikut ini komsep pemanduan Wisata dengan konsep story telling saat kunjungan wisata ke desa wisata Jaka Garong. Berikut ini konsep Story Telling Jaka Garong:

Desa yang terletak di daerah paling utara daerah Istimewa Yogyakarta, membuat para penyamun merasa nyaman di desa ini. Para penyamun ini beroperasi dari daerah Magelang, Klaten, Selatan Yogya dan Sleman. Dengan operasional para penyamun ini membuat warga resah namun prajurit keraton Yogayakarta tidak mampu mencapai aksses di desa ini karena medan yang sangat sulit dilalui oleh kendaraan berkuda. Namun keberadaan mereka sudah diketahui oleh pihak keraton Yogyakarta, sehingga pihak keraton yogyakarta mengirimkan pemuka agama Islam untuk memberikan pencerahan tentang ilmu hidup berdampingan sesuai dengan ajaran agama. Seiring berjalannnya waktu maka para penyamun berhenti menyamun dan memilih bercocok taman karena mereka bearda dalam wilayah tanah bekas guguran lava merapi sehingga tanahnya sangat subur. Dengan modal bercocok tanam ini maka para penyamun mulai berhenti menyamun dan lebih banyak hidup berdampingan dengan rukun dan sejaktera sampai sekarang ini. Untuk meninggalkan citra negatif dari Garong ini maka dirubah menjadi Jaka Garong yang berarti pemuda yang Garang keturuan Garong namun berbudi baik yang mampu menciptakan kedamaian dan kesejahteraan. Itulah yang sejaranh terbentuknya desa wisata Jaka Garong.

Dalam konsep Paket Wisata Desa Wisata Jaka Garong story telling Jaka Garong, para warga selaku pelaku dan pengelola Desa wisata Garongan sangat antusias, hal in terlihat dari keaktifan para peserta dalam mengikuti sesi praktek pembuatan Paket Wisata Desa Wisata Jaka Garong

Pada pelatihan tahap terakhir ini, sangat terlihat progress dan antusias masyarakat dalam mempercantik desa mereka untuk memperoleh kembali deretan pengunjung seperti saat belum terjadi pandemi. Setelah selesai membuat susunan kegiatan dalam paket, peserta latihan berlatih bersama melakukan penghitungan untuk menetapkan harga paket menggunakan lembar penghitungan berikut:

\begin{tabular}{|c|c|c|}
\hline \multicolumn{3}{|c|}{ Tour Quotation Sheet } \\
\hline Komponen Biaya & Biaya Tetap & Biaya Variabel*) \\
\hline Biaya Makan-Minum **) & & \\
\hline Sewa tenda & & \\
\hline Sewa peralatan & & \\
\hline Sewa Pendopo & & \\
\hline Fee pemandu & & \\
\hline Fee crew & & \\
\hline P3K & & \\
\hline Fee administrasi & & \\
\hline Biaya emergency ${ }^{* * x}$ ) & & \\
\hline Jumlah biaya/orang & & \\
\hline Profit Margin/surcharge 15\% & & \\
\hline Komisi Agen $10 \%$ & & \\
\hline HARGA JUAL & & \\
\hline *) biaya tetap : jumlah orang & & \\
\hline **) masih bisa dirinci lagi & & \\
\hline **x) bila diperlukan & & \\
\hline
\end{tabular}

Gambar 8. Lembar penghitungan harga paket 
Pada akhir pelaporan pelaksanaan pelatihan ini, disajikan foto-foto yang menggambarkan penting dilakukannya 'plangisasi' atau pemasangan papan-papan penunjuk arah (showing the way) sebagai pelengkap produk unggulan desa wisata Garongan. Garong Management perlu menentukan (kembali) segmentasi pasar, yang mungkin saja masih sama dengan masa sebelum pandemi, sesuai dengan (pemulihan/pembaharuan) kapasitas/aset yang dimiliki oleh Desa Wisata Garongan.

Tabel 8. Hasil dan Capaian Pendampingan EPP

\begin{tabular}{|c|c|c|}
\hline No & Kondisi Sebelum Pendampingan & Kondisi Setelah Pendampingan \\
\hline 1 & $\begin{array}{l}\text { Paket wisata hanya berfokus pada kegiatan outbond } \\
\text { dengan target wisatawan berasal dari kalangan usia } \\
\text { muda }\end{array}$ & $\begin{array}{l}\text { Paket wisata outbond tetap berjalan namun telah } \\
\text { terdapat paket wisata kegiatan lain seperti susur } \\
\text { sungai, wisata agro kebun salak dll. }\end{array}$ \\
\hline 2 & $\begin{array}{l}\text { Paket wisata dalam jumlah besar. Pengelola Desa } \\
\text { Wisata masih terkendala dalam menyusun paket wisata } \\
\text { dalam jumlah kecil wisatawan. padahal trend wisata di } \\
\text { era adaptasi kebiasaan baru akan menjadi kelompok- } \\
\text { kelompok kecil saja misalnya family tour }\end{array}$ & $\begin{array}{l}\text { Sudah dapat menentukan paket wisata dalam } \\
\text { berbagai alternatif jumlah wisatawan kecil atau besar } \\
\text { yang tepat menguntungkan. } \\
\text { Sudah ada penentuan harga paket wisata untuk } \\
\text { berbagai alternatif jumlah wisatawan }\end{array}$ \\
\hline 3 & Desa wisata menjual paket sendiri & $\begin{array}{l}\text { Terdapat pemahaman baru dalam menjual paket } \\
\text { wisata melalui agent perjalanan/tour and travel }\end{array}$ \\
\hline
\end{tabular}

Tabel 9. Hasil Pendampingan berupa perhitungan paket Wisata Desa Wisata Garongan

\begin{tabular}{lrr}
\hline \multicolumn{1}{c}{ Tour Cost Component } & Biaya Tetap & Biaya Tidak Tetap \\
\hline Welcome drink & & 5.000 \\
Makan siang & & 13.000 \\
Makan malam & 100.000 & 13.000 \\
Sewa tenda/pendopo & 100.000 & \\
Fee guide & 50.000 & \\
Service crew & 5.000 & \\
Biaya administrasi & 10.000 & \\
Biaya lain- lain (sound system dl1) & 25.000 & \\
P3k & $\mathbf{2 9 0 . 0 0 0}$ & $\mathbf{3 1 . 0 0 0}$ \\
\hline Total cost & $\mathbf{4 8 . 3 3 3}$ & $\mathbf{7 9 . 3 3 3}$ \\
Cost per pax Per 10 Orang & & $\mathbf{7 . 9 3 3}$ \\
Surcharge (10\% Xc19) & & \\
Net Price (60000+6000) & & $\mathbf{8 7 . 2 6 7}$
\end{tabular}

\section{Pelatihan Kepemanduan: Bahasa Inggris untuk Pemanduan Wisatadan Pengenalan Lintas Budaya}

Pelatihan kepemanduan untuk pemandu lokal di Desa Wisata Garongan sangat perlu dilakukan. Pelatihan tersebut fokus dalam penggunaan bahasa asing yaitu Bahasa Inggris. Meningkatnya wisatawan asing yang melancong ke Indonesia dengan tujuan pedesaan, makadirasa pemandu wisata di desa wisata perlu penguasaan bahasa internasional untuk memudahkan dalam berkomunikasi, tidak terkecuali pemandu wisata di Desa Wisata Garongan. Selain bahasa Inggris, dalam pelatihan ini juga diajarkan pemahaman terkait budaya antar bangsa, lebih spesifik tentang perilaku yang etis saat bertemu wisatawan asing dari berbagai negara (lintas budaya).

Pelatihan kepemanduan ini diselengarakan di Joglo Desa Wisata Garongan, Wonokerto, Turi, Sleman dan diikuti oleh 16 peserta. Program pelatihan ini dilaksanakan 2 jam, namunselebihnya tetap dilanjutkan pada kegiatan pendampingan, dengan pelatihan-pelatihan aplikatif lainnya. Dengan waktu yang sangat cukup efektif untuk memberikan pelatihan Bahasa Inggris, maka program ini dibagi menjadi dua tema yaitu pengetahuan lintas budaya dan pembekalan penggunakan vocabulary yang sering digunakan dalam kepemanduan. 
Pelatihan kepemanduan diawali dengan pengetahuan dan pemahaman lintas budaya atau disebut dengan cross cultural understanding. Secara spesifik, pelatihan ini fokus dalam"bagaimana menyambut wisatawan asing dari berbagai negara". Ada berbagai macam cara menyambut wisatawan dari mancanegara oleh karena itu dalam hal ini etika bersalaman (greeting etique) dari berbagai negara seperti, Thailand, Kenya, Korea Selatan, China, Amerika Serikat, Australia dan kamboja.

Untuk memudahkan materi greeting etique ini diterima lebih mudah oleh pemandu lokal di destinasi di sana, maka pelatihan ini tersaji dengan cara menampilkan melalui presentasi video dengan durasi 3 menit 31 detik. Dengan menjeda sertiap slide negara dalam melakukan greeting,maka materi ini diharapkan dapat diterima dengan mudah.

Selanjutnya untuk mengetahui sejauh mana materi ini dapat diterima peserta pelatihan, maka pelatih memberikan kesempatan kepada para pemandu lokal di destinasi Desa Wisata Garonganuntuk menanggapi dan memberikan komentar setiap kali video tersebut ditayangkan. Dengan model presentasi seperti ini, peserta pelatihan dapat merespon dengan fokus memperhatikan dan tampak langsung memprektikkan dengan kerabat yang duduk di sampingnya tanpa menuggu intruksi. Tampak salah seorang peserta pelatihan teesenyum melihat cara greeting dari negara lain yang tampak aneh dilakukan. Berikut adalah contoh gambar greeting etique dari beberapa negara asing yaitu:

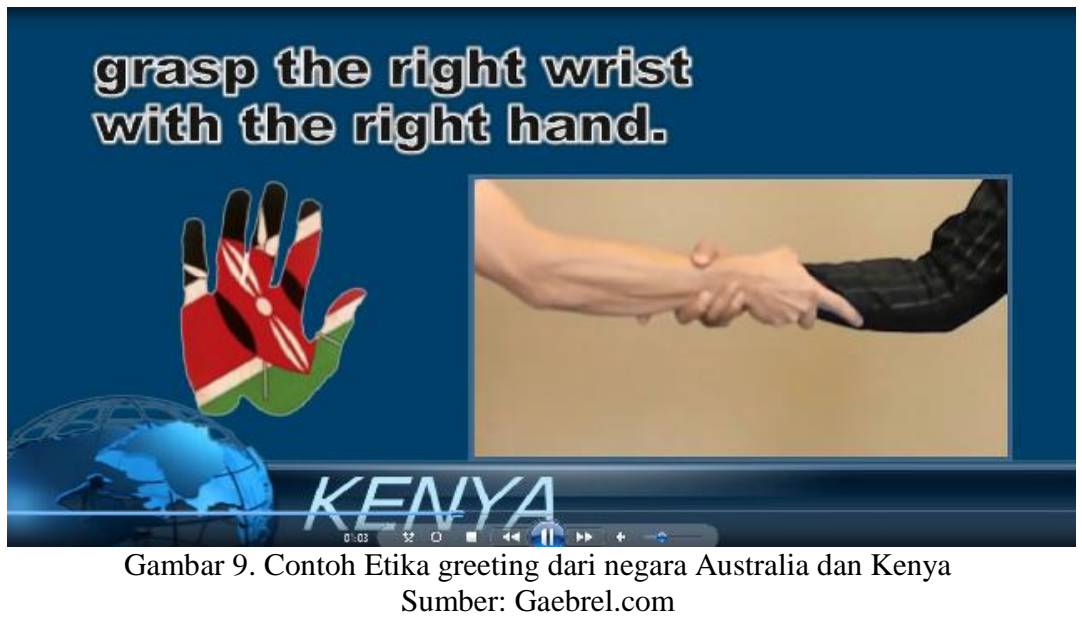

Kedua, materi yang disampaikan dalam program ini penjelasan penggunaan vocabulary yang sering digunakan dalam kepemanduan. Pelatihan ini untuk memperdalam tentang menggunaan verb, noun dan adjective.

Tabel 10. Hasil dan Capaian Pendampingan Kepemanduan

\begin{tabular}{|c|c|}
\hline & \\
\hline $\begin{array}{l}\text { Anggota Pokdarwis Desa Wisata Garongan mayoritas } \\
\text { memiliki latar belakang sebagai mantan Tenaga Kerja } \\
\text { Indonesia (TKI) yang dahulu bekerja di berbagai negara. Pada } \\
\text { dasaranya Mitra merupakan orang-orang yang pandai } \\
\text { berbahasa Asing terutama bahasa Inggris. }\end{array}$ & $\begin{array}{l}\text { tkan pengetahuan yang baru dalam etika } \\
\text { Inggris untuk Kepemanduan Wisata. } \\
\text { miliki wawasan baru dalam hal etika } \\
\text { antar bangsa yang diharapkan akan } \\
\text { at saat memandu wisatawan asing. }\end{array}$ \\
\hline
\end{tabular}

\section{Pendampingan Pengelolaan Keuangan}

Sosialisasi pengelolaan keuangan merupakan program yang diharapkan oleh masyarakat di Desa Wisata Garongan, mengingat masih minimnya pemahaman pengelola dalam hal manajemen keuangan.Sasaran dari pelatihan ini adalah Pokdarwis selaku pengelola Desa Wisata Garongan. Capaian yang diharapkan dari program ini yaitu meningkatnya kemampuan pengelola dalam hal manajemen keuangan desa wisata.

Usaha di bidang pariwisata khususnya desa wisata menuntut adanya manajemen keuangan yang extra ketat, disertai control dan alokasi anggaran yang benar-benar efektif, dan efisien, serta diharapkan membawa untung berupa profit dan kesejahteraan usaha jangka panjang. 


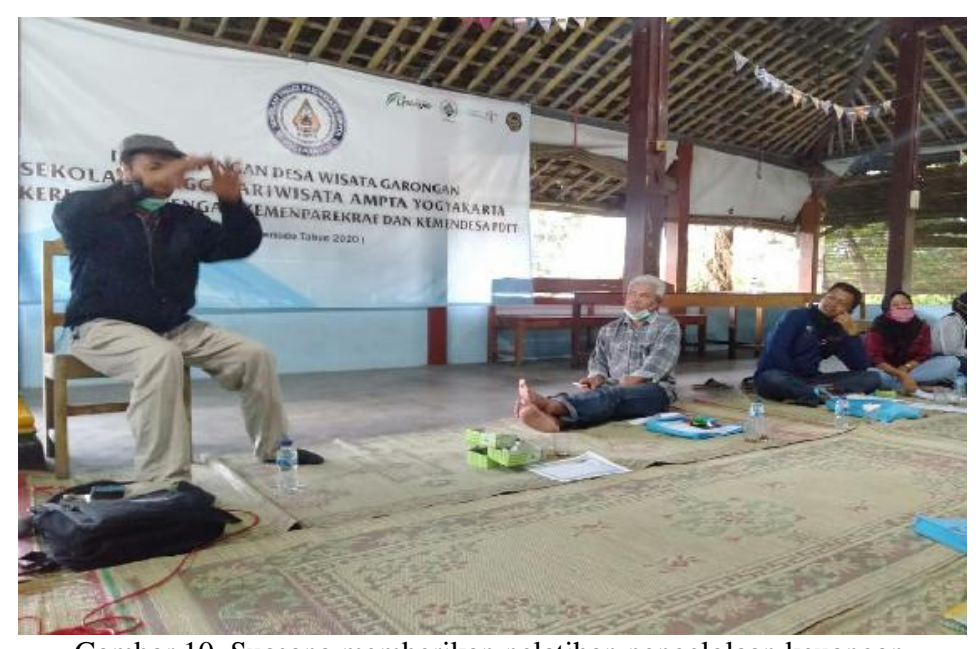

Gambar 10. Suasana memberikan pelatihan pengelolaan keuangan

Walaupun bisnis desa wisata sangat prospektif, namun bisnis pariwisata merupakan jenis bisnis yang sangat fluktuatif. Fluktuatif berarti banyak gejolak, bisnis bisa cepat naik signifikan dan bisa juga turun drastis dalam sekejap. Fluktuasi pasar wisata juga sangat tergantung pada tingkat daya beli konsumen, isu politik, isu keamanan, transportasi, event/ liburan, gejolak ekonomi dan lain sebagainya, seperti pada saat ini terkait dengan adanya pandemi Covid-19. Perubahan-perubahan atau gejolak tersebut setiap saat akan mempengaruhi pencapaian keuntungan desa wisata.

Fenomena yang terjadi di Desa Wisata Garongan belum terlihat adanya planning yang matang dalam hal pengelolaan keuangan. Kebutuhan pembangunan yang pasti, berbadning terbalik dengan pemasukan yang tidak kontinyu sehingga turut membuat rumit sistem keuangan yang ada.

Berdasarkan kondisi tersebut, maka dalam bisnis wisata dituntut adanya perencanaan dan manajemen keuangan yang matang. Seorang manajer keuangan dalam bisnis pariwisata dituntut untuk peka membaca situasi dan responsif terhadap perubahan dalam menetapkan berbagai kebijakan keuangan. Sehingga desa wisata tetap mampu mendapat keuntungan meskipun lingkungan bisnis berfluktuasi.

Terkait manajemen keuangan, dalam pelatihan ini ini dibahas beberapa metode aplikatif membuat laporan keuangan yang dapat membantu pengeloa desa wisata dalam membuat kebiajkan keuangan, sesuai dengan tuntutan karakteristik bisnis pariwisata yang fluktuatif seperti diuraikan diatas. Laporan keuangan yang diajarkan dalam pelatihan meliputi hal-hal berikut.

1. Membuat neraca

Neraca keuangan adalah laporan yang bertujuan memberikan informasi nilai bersih kekayaan desa wisata pada waktu laporan tersebut dibuat.

2. Laporan rugi/laba

Laporan rugi/laba adalah untuk memberikan informasi tentang laba ataupun kerugian hotel secara keseluruhan.

3. Laporan arus kas

Laporan arus kas adalah laporan yang menyajikan informasi-informasi yang dibutuhkan untuk memenuhi kebutuhan tujuan laporan keuangan hotel secara menyeluruh. Laporan arus kas memberikan informasi rinci tentang arus kas masuk dan arus kas keluar. Selain itu, laporan arus kas (cash flow) membantu pengelolaan untuk mendapatkan informasi tentang : bagaimana neraca desa wisata selalu mengalami perubahan dari awal sampai akhir periode akutansi.

Dalam pelatihan trainer sudah memberikan spreatsheet yang dapat digunakan lamgsung dalam membuat laporan keuangan. Selain membuat laporan keuangan, dalam pelatihan peserta juga dilatih untuk dapat membuat kebijakan keuangan atau manajemen keuangan. Manajemen keuangan kegiatanya meliputi perencanaan pencarian dana dan pembelanjaan, alokasi dana untuk investasi, pemupukan dana desa wisata dan pemeliharaan struktur modal yang sehat. 
Perubahan lingkungan bisnis yang sangat dinamis seperti telah diuraikan sebelumnya menuntut manajemen untuk terus mengelola keuanganya secara cermat, baik untuk membiayai operasional maupun investasi guna memenuhi tuntutan perubahan pasar. Hanya desa wisata dengan pengelolaan keuangan yang baik yang akan bertahan hidup. Dan hal ini sudah terbukti di berbagai daerah.

Manajemen keuangan fungsinya memberikan suatu imput bagi manajemen untuk mengambil keputusan terhadap rencana-rencana manajemen dalam menghadapi setiap perubahan. Dalam menghadapi setiap perubahan tersebut Manajemen Keuangan mempunyai fungsi utama yaitu:

Membuat solusi keputusan investasi

Meanajemen keuangan memberikan solusi hasil analisi terhadap beberapa pilihan manajemen mengenai investasi. Memberikan pilihan pada investasi yang paling menguntungkan dengan risiko yang paling kecil. Contoh kasus: pertimbangan dalam membuat suatu investasi desa wisata, manajemen ingin memiliki sebuah bus sebagai aset tetap, atau lebih menguntungkan dengan menyewa saja kepada perusahan lain.

\section{Membuat kepuatusan keuangan}

Keputusan keuangan yang dimaksud meliputi pemenuhan pendanaan untuk keperluan investasi. Apakah seluruhnya didanai dengan modal sendiri atau tidak (sebagian hutang). Dengan perhitungan pendanaan, diharapkan akan memberikan jaminan keuangan perusahaan tetap sehat.

\section{Keputusan pengelolaan aset}

Manajemen keuangan memberikan analisis mengenai kebutuhan operasional dalam pengelolaan aset. Keputusan ini berkaitan dengan pengelolaan kas yang mencukupi pembiayaan operasional, pengumpulan piutang untuk memenuhi kecukupan kas, serta pengelolaan persediaan yang efisien.

Pedoman dalam menjalankan fungsi keuangan dan membuat keputusan bagi manajer adalah sebagai berikut : (1) Pilih yang paling menguntungkan; (2) Hindari atau minimalisir risiko; (3) Membagi investasi, membagi investasi dalam berbagai bentuk adalah hal yang paling aman dan menguntungkan untuk menghindari risiko usaha; (4) Tambahan benefit, suatu investasi dianggap menguntungkan apabila memberikan tambahan pendapatan atau penghematan; (5) Informasi lengkap, tanpa data keputusan atau kesimpulan yang dihasilkan akan berisiko tinggi; (6) Keseimbangan antara risiko dan hasil

Nilai waktu, perlu diingat bahwa nilai uang dari waktu ke waktu terus mengalami penurunan. Investasi yang sepintas menguntungkan, namun jangka waktu lama dibutuhkan dalam memperloh keuntungan tersebut, bisa jadi sebenarnya profit

Tabel 11. Hasil dan Capaian Pendampingan Pengelolaan Keuangan Desa Wisata

\begin{tabular}{clll}
\hline No & \multicolumn{1}{c}{ Kondisi Sebelum Pendampingan } & \multicolumn{2}{c}{ Kondisi Setelah Pendampingan } \\
\hline 1 & $\begin{array}{l}\text { Mitra mengalami kendala dalam menyusun laporan } \\
\text { keuangan dan pembukuan }\end{array}$ & $\begin{array}{l}\text { Sudah memiliki pemahaman yang baik dalam } \\
\text { menyusun pembukuan/laporan keuangan }\end{array}$ \\
2 & $\begin{array}{l}\text { Perencaan keuangan untuk pelaksanaan program desa } \\
\text { wisata belum ada. Mayoritas program pembangunan } \\
\text { masih dimanajemen secara acidential }\end{array}$ & $\begin{array}{l}\text { Sudah memiliki pemahaman untuk membuat } \\
\text { perencanaan keuangan }\end{array}$ \\
\hline
\end{tabular}

\section{Simpulan}

Perogram pendampingan secara umum berjalan lancar, Mitra sangat antusias dalam mengikuti berbagai program pelatihan yang diberikan. Walaupun program pendampingan lebih bersifat pembangunan non fisik namun telah terlihat dampak yang nyata yang dirasakan wisatawan berupa peningkatan pemahaman dan keterampilan. Pelaku pariwisata juga telah tergerak hatinya untuk melakukan perbaikan sarana fisik secara swadaya.Sehingga dapat disimpulkan bahwa pendamping cukup berhasil berperan sebagai motivator, komunikator, edukator, fasilitator, supervisor, evaluator. 
Terdapat enam (6) program unggulan dalam pendampingan desa wisata yang disusun berdasarkan kebutuhan Mitra dalam hal ini Desa Wisata Garongan, seperti: sapta pesona; pelayanan prima;pelatihan penerapan protokol kesehatan CHSE; pelatihan pengelolaan homestay; pelatihan pengembangan produk wisata; pelatihan kepemanduan; dan pelatihan keuangan.

Secara keseluruhan, program-program diterima Mitra dengan baik. Peserta pelatihan selalu terlihat antusias dan kehadiran selalu penuh sesuai jumlah undangan.

Pendampingan desa wisata berdampak secara positif bagi Desa Wisata Garongan khususnya bagi pelaku usaha pariwisata. Hal ini terlihat dari adanyamasyarakat yang tergerak secara swadaya untuk memperbaiki sarana dan prasarana usaha pariwisatanya. Desa wisata Garongan saat ini telah berisap menyambut kedatangan pariwisata di era adaptasi kebiasaan baru dengan pembangunan secara swadaya untuk penyediaan sarana pendukung protokol kesehatan, misalnya: SOP penanganan pengunjung, pembangunan wastafel untuk cuci tangan dan lain sebagainya.

\section{Ucapan Terima Kasih}

Program Pendampingan Desa Wisata Garongan yang dilaksanakan Sekolah Tinggi Pariwisata AMPTA Yogyakarta atas kerjasama dengan Kementrian Pariwisata dan Ekonomi Kreatif Republik Indonesia/Badan Kementrian Pariwisata dan Ekonomi Kreatif Republik Indonesia dan Kementrian Desa PDTT Republik Indonesia telah sukses dilaksanakan.

Kami ucapkan terikasih kepada pihak-pihak terkait yang telah berpartisipasi dalam mendukung program pendampingan, khususnya kepada:

1. Dinas Pariwisata Kabupaten Sleman

2. Bapak Tomon Haryo Wirosobo selaku Lurah Desa Wonokerto

3. Bapak Agus Sugiarto selaku Ketua Kelompok Sadar Wisata Desa Wisata Garongan

4. Hotel Royal Ambarokmo

5. Rekan-rekan dosen dan mahasiswa Sekolah Tinggi Pariwisata AMPTA Yogyakarta

\section{Referensi}

AICST, A. (2006). Plan of Action for Sustainable Tourism Management in asia and the Pacific. Phase (2006-2012).

Basiya, R., \& Rozak, H. A. (2012). Kualitas Daya Tarik Wisata, Kepuasan dan Niat Kunjungan Kembali Wisatawan Mancanegara di Jawa Tengah. Jurnal Ilmiah Dinamika Kepariwisataan, 11(2). Retrieved https://www.unisbank.ac.id/ojs/index.php/pdk1/article/view/1715/0

Dyah, K., \& Abdul, S. (2016). Pengaruh Kulaitas Layanan dan Keunggulan Produk terhadap Kepuasan Pelanggan dan Dampaknya pada Komunikassi Words of Mouth: Studi pada PD BPR BKK Demak Cabang Sayung, Kab.Demak. Jurnal Administrasi Bisnis, 5(1), 46-55. Retrieved https://ejournal.undip.ac.id/index.php/janis/article/view/12723

Edi Darmawi. (2010). Pengembangan Kepariwisataan Berbasis Masyarakat di Kota Bengkulu. Jurnal Ilmiah IDEA (Vol. 4).

Febriany, C. D. K. (2014). Pengaruh Kualitas Pelayanan dan Fasilitas terhadap Kepuasan Wisatawan di Cikole Jayagiri Resort Bandung (Doctoral dissertation, Universitas Pendidikan Indonesia). Retrieved http://repository.upi.edu/13591/

Gendro, W. (2019). Efek Partisipasi Masyarakat terhadap Kepuasan dan WOM Destinasi Wisata Candi Borobudur. Upajiwa Dewantara, 3(1), 54-66. Retrieved https://jurnal.ustjogja.ac.id/index.php/upajiwa/article/view/4523

World Health Organization. (2003). Guidelines for safe recreational water environments: Coastal and fresh waters (Vol. 1). World Health Organization. Retrieved https://books.google.com/books?hl=id\&lr=\&id=D9pNrH6U0oYC\&oi=fnd\&pg=PR7\&dq=Guid elines+for+Safe+Recreational+Water.+Volume+1,+Coastal+and+Fresh+Waters.+(2003).+Risk +Management+(Vol.+1).+\&ots=Uvjh7LgTGF\&sig=XVX8i6lHHtqYsv7wgxkGP2n3xrs 
Hermantoro, H. (2014). Creative-Based Tourism: Dari Wisata Rekreatif menuju Wisata Kreatif. LAP LAMBERT Academic Publishing.

Hermawan, H., Wijayanti, A., \& Nugroho, D. S. (2019). Loyalty on Ecotourism analysed using the factors of tourist attraction, safety, and amenities, with satisfaction as an intervening variable.African Journal of Hospitality. African Journal of Hospitality, Tourism and Leisure, 8(1). Retrieved https://www.ajhtl.com/uploads/7/1/6/3/7163688/article_31_vol_8 5 2019 indonesia.pdf

Hermawan, H., Brahmanto, E., \& Hamzah, F. (2018). Pengantar Manajemen Hospitality. Pekalongan: Penerbit NEM.

Hurriyati, R. (2005). Bauran Pemasaran dan Loyalitas Pelanggan. Bandung: Alfabeta.

Kyrgyz Community Based Tourism. (2017). Retrieved www.cbtkyrgyztan.kg

Nasution, S., Nasution, M. A., \& Damanik, J. (2009). Persepsi Wisatawan Mancanegara Terhadap Kualitas Objek dan Daya Tarik Wisata (ODTW) Sumatera Utara.

Pitana, I. (2009). Pengantar Ilmu Pariwisata. Yogyakarta: andi

Saleh, F., \& Ryan, C. (1991). Analysing service quality in the hospitality industry using the SERVQUAL model. Service Industries Journal, 11(3), 324-345. Retrieved https://www.tandfonline.com/doi/abs/10.1080/02642069100000049

Selang, C. A. D. (2013). Bauran Pemasaran (Marketing Mix) Pengaruhnya Terhadap Loyalitas Konsumen pada Fresh Mart Bahu Mall Manado. Jurnal Riset Ekonomi, Manajemen Bisnis Dan Akuntansi, 1(3). Retrieved https://ejournal.unsrat.ac.id/index.php/emba/article/view/1374

Sopyan, S., \& Widiyanto, I. (2015). Analisi Pengaruh Daya Tarik Wisata dan Kualitas Pelayanan Terhadap Minat Berkunjung Ulang Pengunjung dengan Kepuasan Pengunjung Sebagai Variabel Intervening (Studi pada Cagar Budaya Gedung Lawang Sewu). Fakultas Ekonomika dan Bisnis. Retrieved http://jurnal.umt.ac.id/index.php/dmj/article/view/4101

Suansri, P., Yeejaw-haw, S., \& Richards, P. (2013). CBT standard handbook. Chiang Mai: The Thailand Community-Based Tourism Institute.

Tarunajaya, W.B., Setiawan, B., Simanjutak, D., Afriza, L., Palupi, S., Ariani, V., Hutagalung, M.H. (2020). Buku Saku Pemberdayaan Masyarakat Desa Wisata Berbasis Pendampingan: Kerjasama Kemenparekraf, Kemendes PDTT dan Perguruan Tinggi. Jakarta: Direktorat Pengembangan SDM Pariwisata Kemetrian Pariwisata dan Ekonomi Kreatif.

Tjiptono, F., \& Chandra, G. (2011). Service, Quality and Satisfaction. Yogyakarta: Andi Offset.

Wallin Andreassen, T., \& Lindestad, B. (1998). Customer Loyalty and Complex Services: The Impact of Corporate Image on Quality, Customer Satisfaction And Loyalty for Customers With Varying Degrees of Service Expertise. International Journal of Service Industry Management, 9(1), 7-23. Retrieved

https://www.emerald.com/insight/content/doi/10.1108/09564239810199923/full/html?journalC ode $=$ ijsim

Yudistira, I. G. A. A., \& Susanto, A. (2012). Keselamatan Pengunjung Tempat Wisata. Widya, 29(320).

Pemerintah Indonesia. (2011). Peraturan Pemerintah No. 50 Tahun 2011 Yang

Mengatur Tentang Rencana Induk Pembangunan Kepariwisataan Nasional Tahun 20102025.

Sekretariat Negara. Jakarta. 